This article has been scanned by iThenticat No plagiarism detected

Volume ‘3 Issue ‘4 August 2021

p. 159-179

\title{
HONOR CRIMES AND ITS LEGAL AND SOCIAL IMPACTS، MURDER IS A WASH OF SHAME AS A MODEL
}

http://dx.doi.org/10.47832/2757-5403.4-3.15

\section{Bushra Salman Hussain AL OBAIDI 1}

\begin{abstract}
:
The importance of research: The heavenly canons and all laws affirm the guarantee of everyone's right to life, but a look at daily practices reveals that a large number of women are killed daily under the background of honor killings. His race and his religion, is considered today a necessity and a priority heavily placed on the collective conscience.

The exacerbation of the phenomenon of honor murders, or the liquidation of women who has rebel against family laws, and the pretext that she is an adulterer, is a dangerous indication of underestimating the right of women to life and is a sign of social discrimination practiced on the basis of gender.

The phenomenon of the exacerbation of honor murders indicates a crisis of relationships within the family and society, a crisis of relations within the community of women, the continued dominance of some customs over laws in contemporary societies, and the institutionalization of violence against women and their sacrifice.

Iraq society is a tribal society and accepts the idea of killing of women as a means of dishonor. However, killings under this concept have increased as a result of the tyranny of tribal values, and they increased even more after the occupation of Iraq on 9/ 4 / 2003

Research objectives: abolishing the legal articles that encourage the killing of women under any pretext, and making the crime of murder under the pretext of washing shame a premeditated murder, like all murders, and subject to its provisions without wearing the garment of a mitigating excuse and allowing the perpetrators to escape from punishment and activating the implementation of international conventions and respecting them. Part of the national legislation for ratification by Iraq. As well as respect for the constitutional texts being the highest in the application.

When talking about treating this crime and setting up a solution for it, the law must be the other side, without a law that protects women,

${ }^{1}$ Dr. , Al-Mustafa University College, Iraq, d bushra alaubadi@yahoo.com, https://orcid.org/0000-0003-3484$\underline{0692}$
\end{abstract}

Copyright (C) Published by IJHER Journal, www.ijherjournal.com

Rimar Academy, Fatih, Istanbul, 34093 Turkey

All rights reserved 
clarifies the limits and provisions of this crime, and establishes appropriate punishment for its images in a way that does not allow the perpetrators to escape from punishment, then there will be no benefit from all that was said It is said about violence against women.

Key words: Honor Crimes, Murder Is A Wash of Shame, Women.

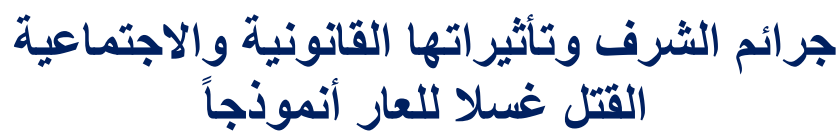

بشرى سلمان حسين العبيدي2

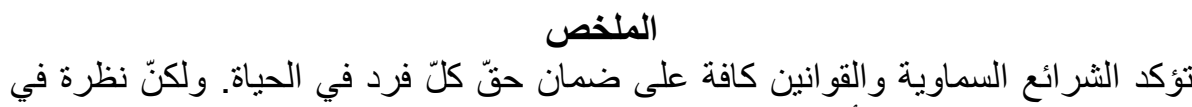

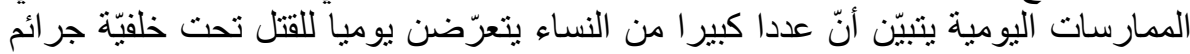

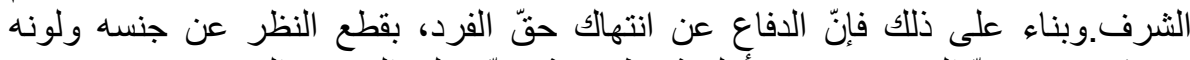

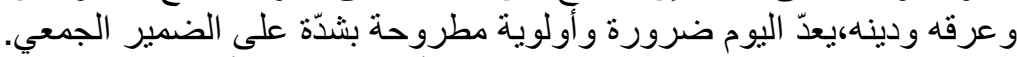

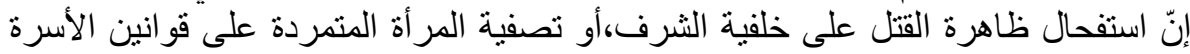

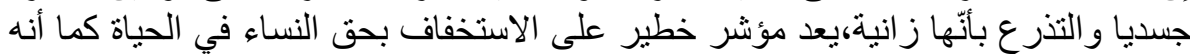
علامة دالة على التمييز الاجنماعي الممارس علئ على أساس الجنس.

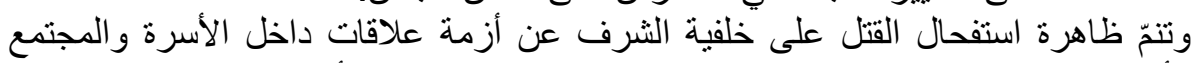

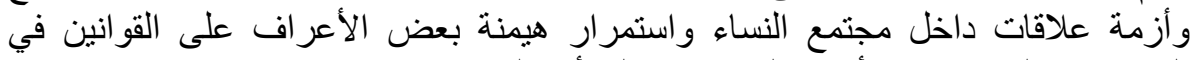

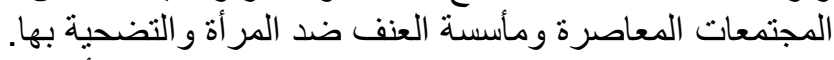

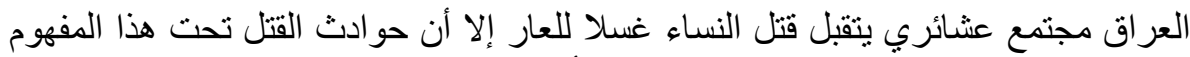

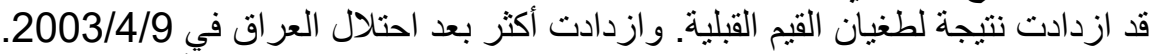

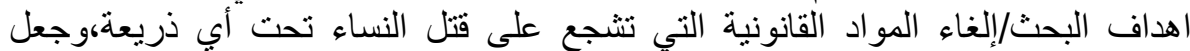

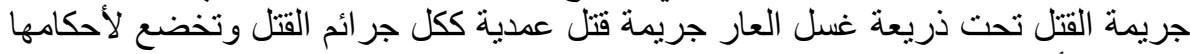

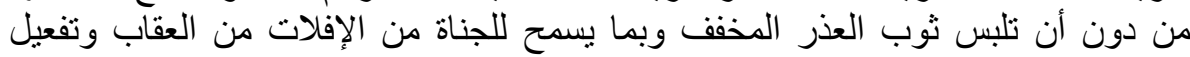

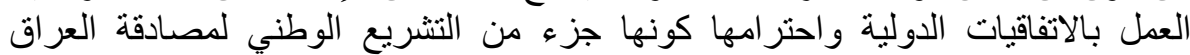

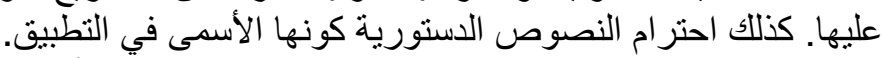

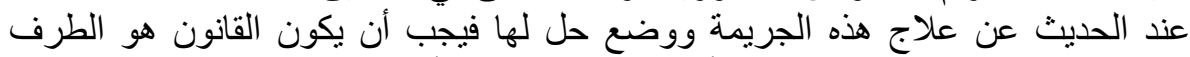

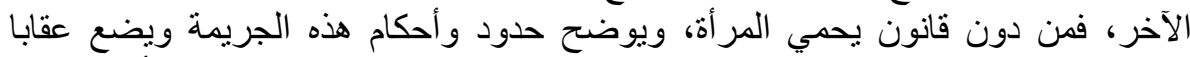

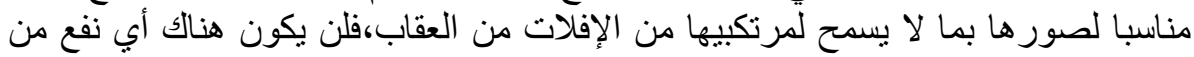

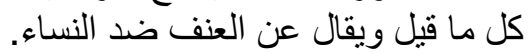

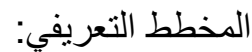

المطلب الأول: المعالجة القانونية للقتل غسلا للعار

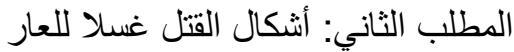

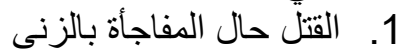
2. القتل تحت ذريعة البو اعث الثريفة

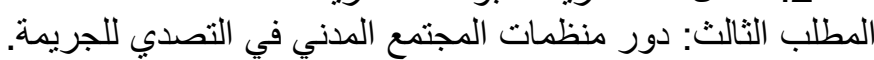

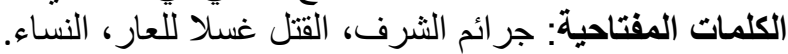

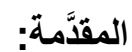

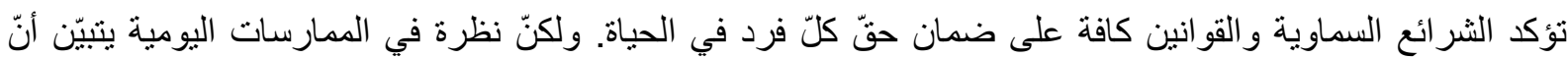

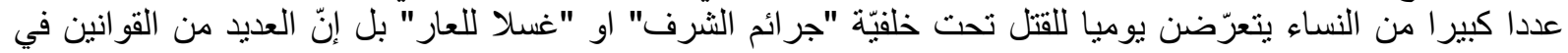

d bushra alaubadi@yahoo.com 2د. 


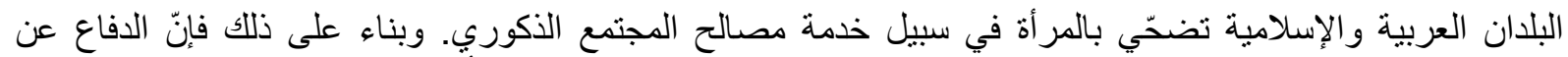

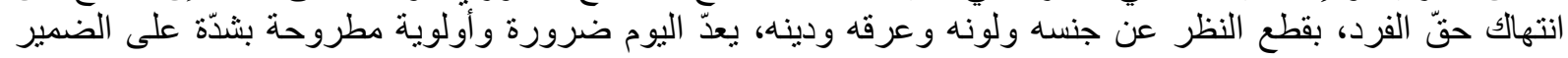

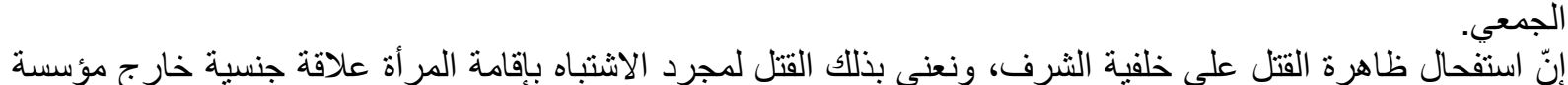

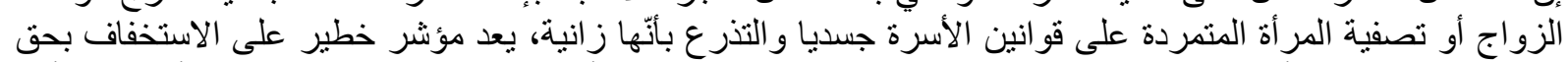

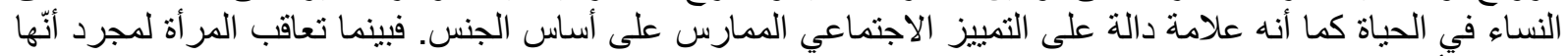

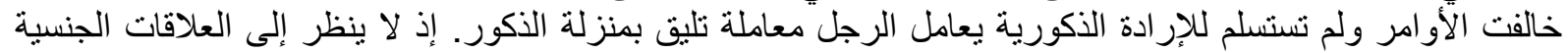

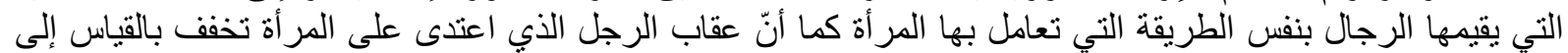

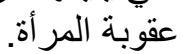

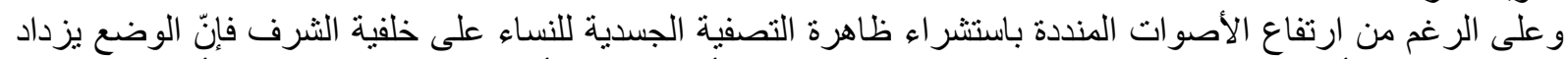

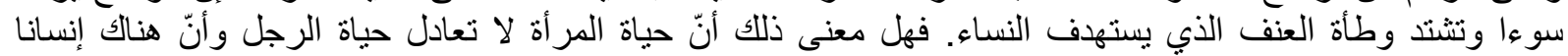

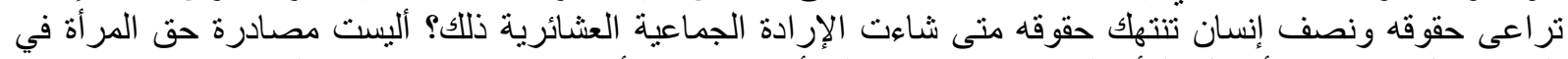

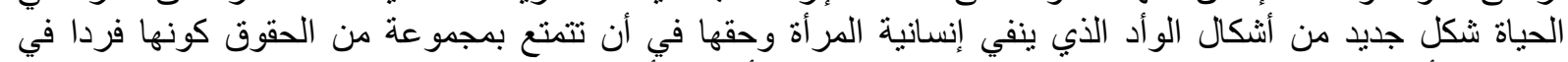

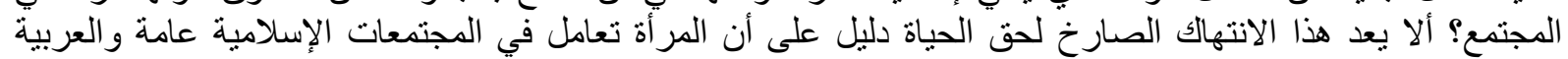

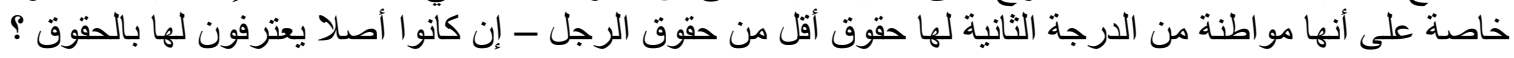

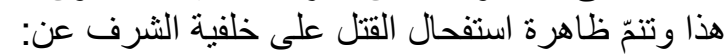

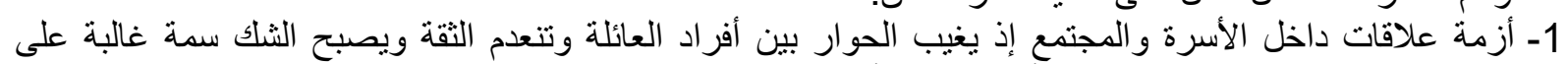

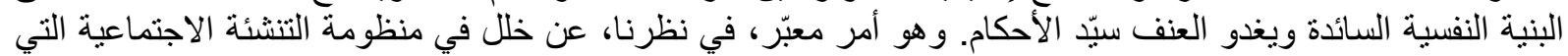

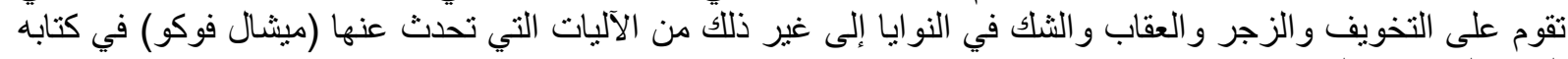

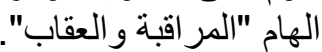

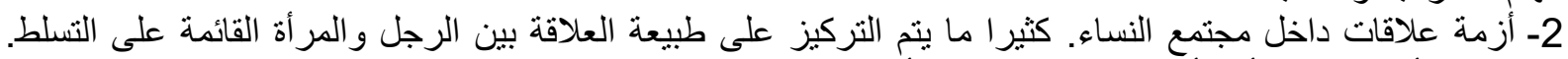

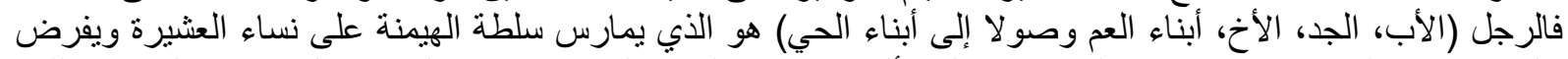

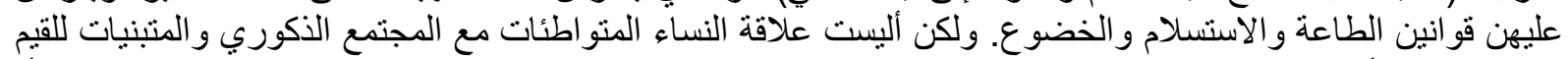

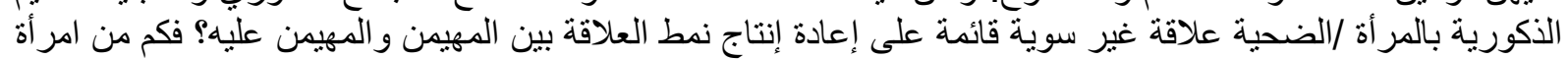

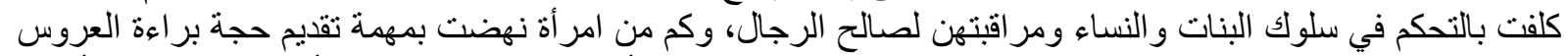

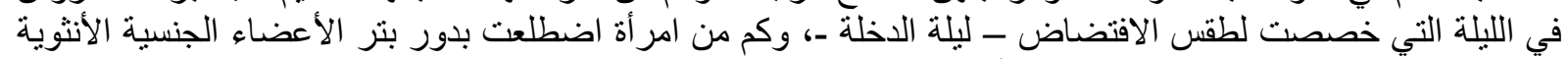

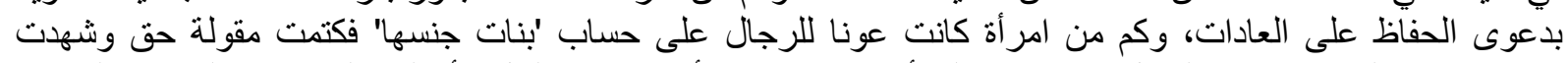

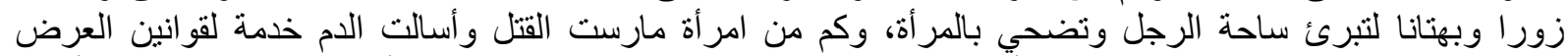

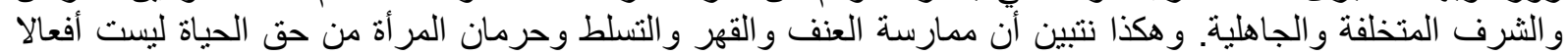

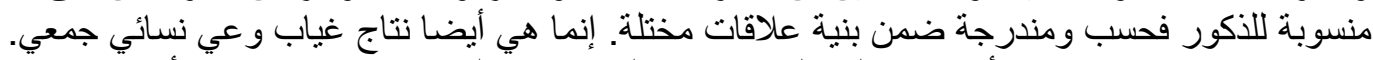

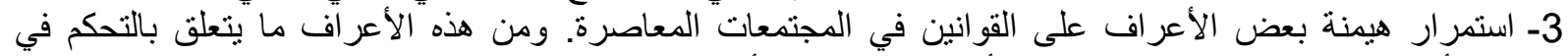

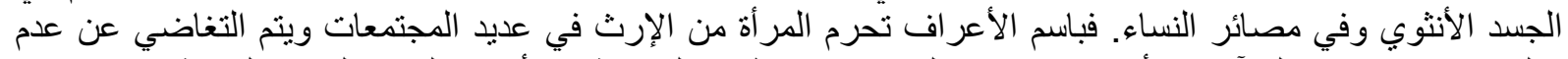

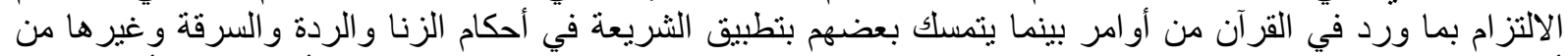

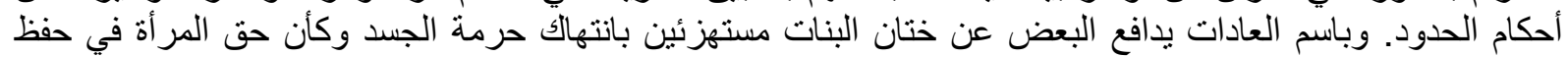

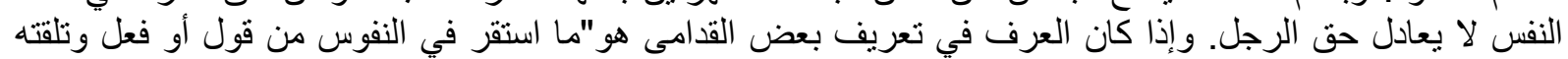

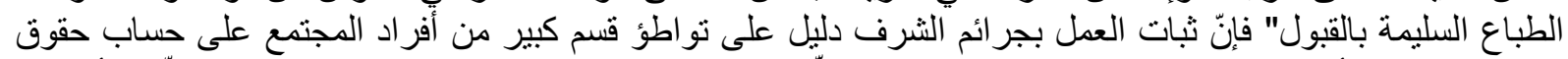

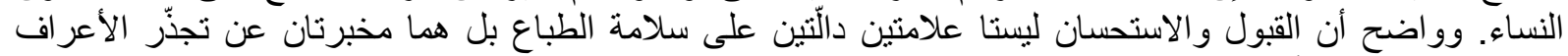

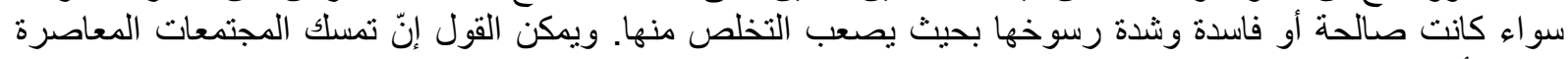

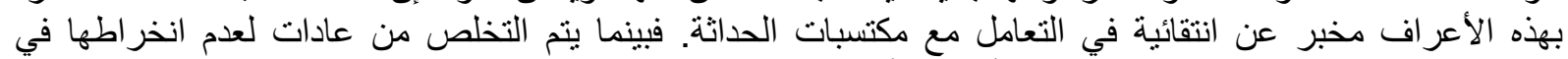

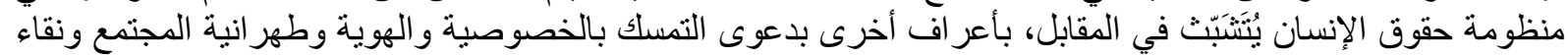

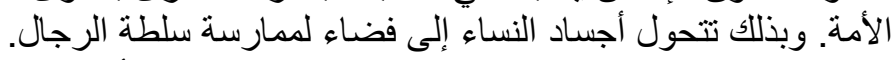

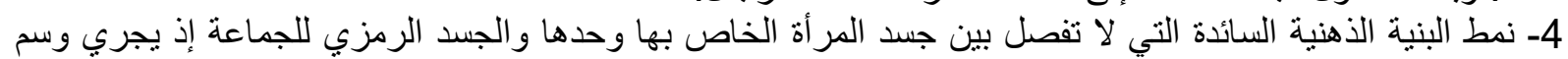

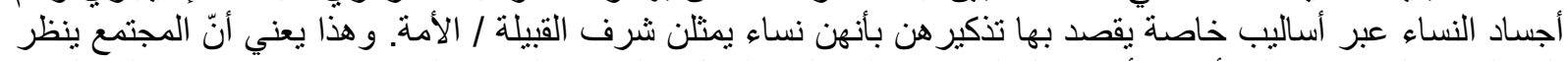

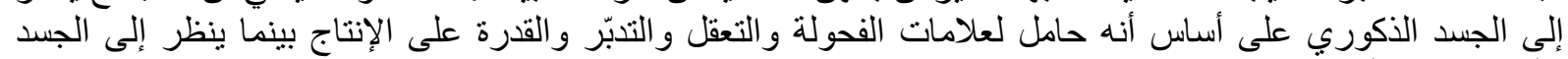

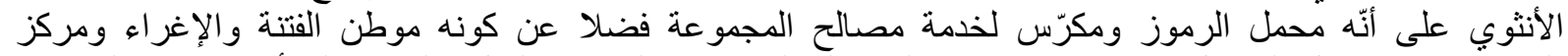

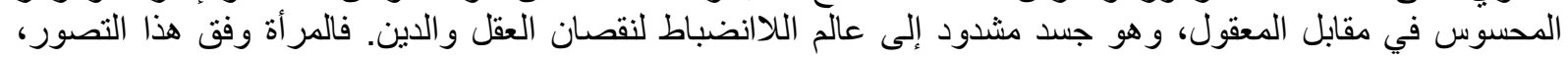

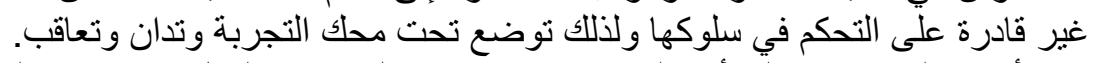

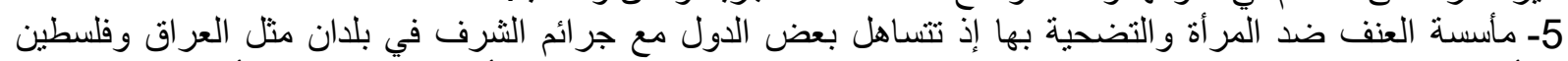

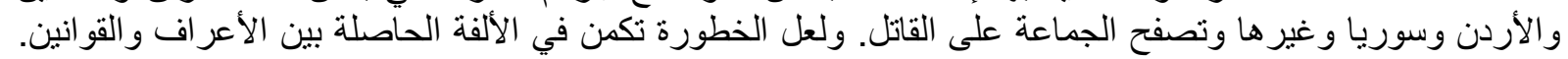




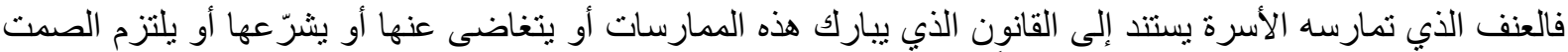

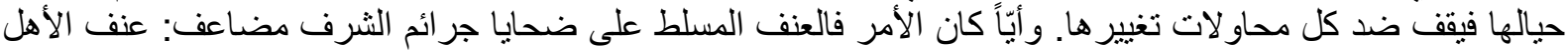

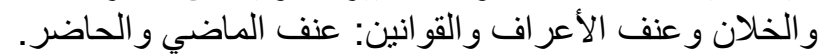
6- إنّ سلب المر أة حق الحياة مردّه نظرة المجتمع إلى جنسانيتها التي تعتبر مهددة للنظام الاجتماعي ومخلخلة لكينونة

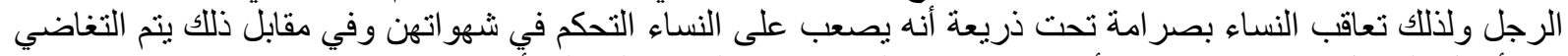

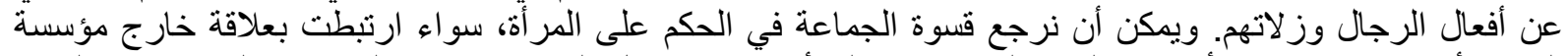

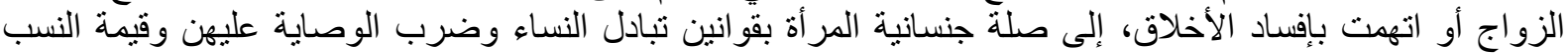

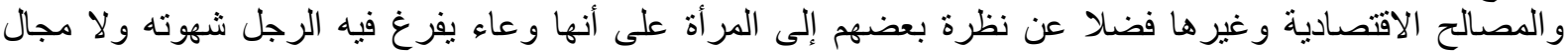

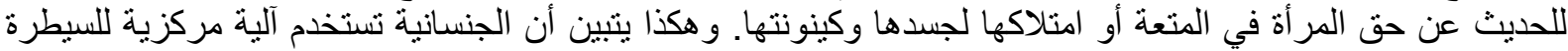

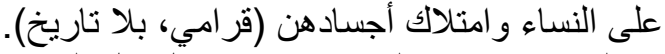

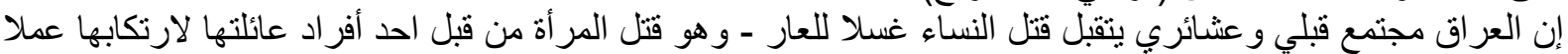
مخلا بالثرف يجلب العار للعائلة - إلا أن حوادث القئل القتل تحت هذا المفهوم قد ازدادت نتيجة لطغيان القيم المحافظة.

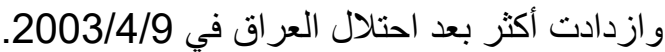

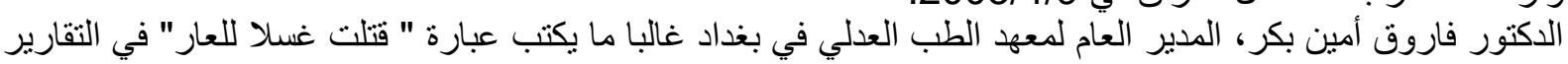

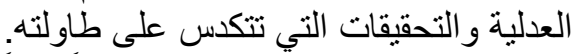

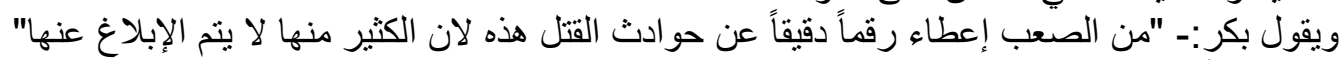

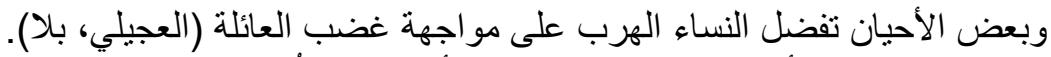

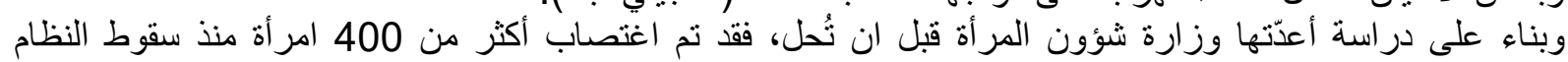

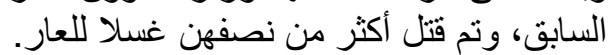

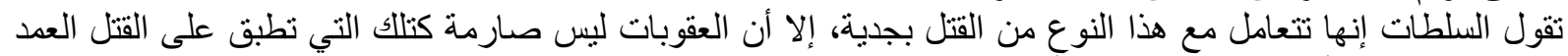

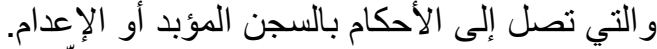

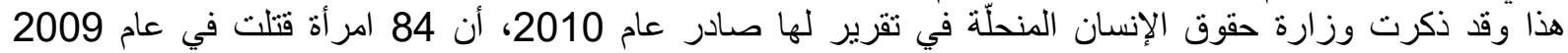

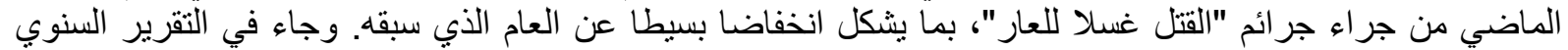

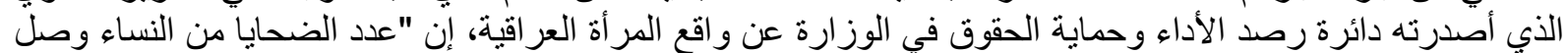

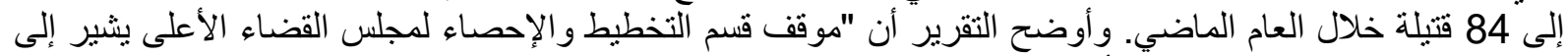

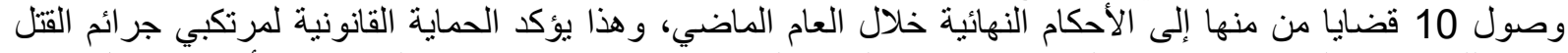

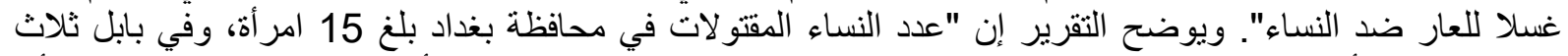

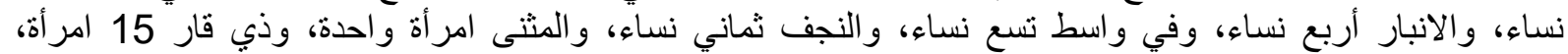

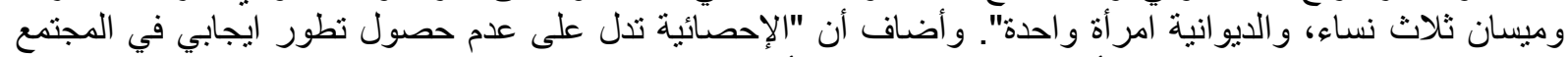

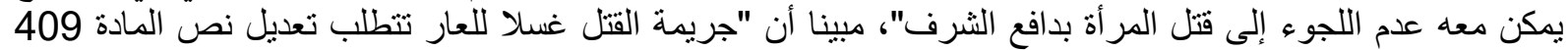

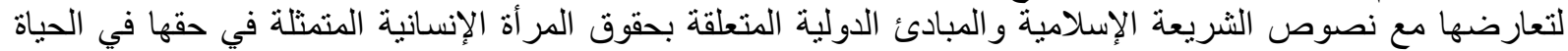

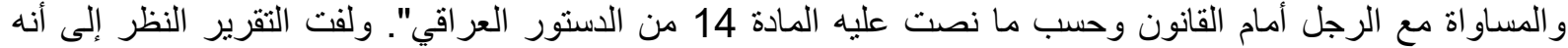

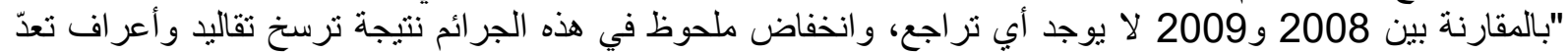

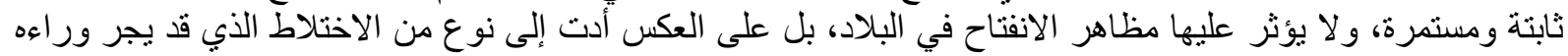

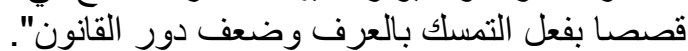

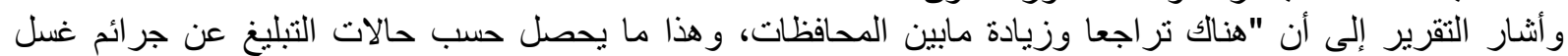

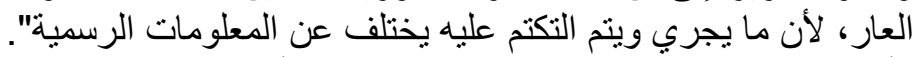

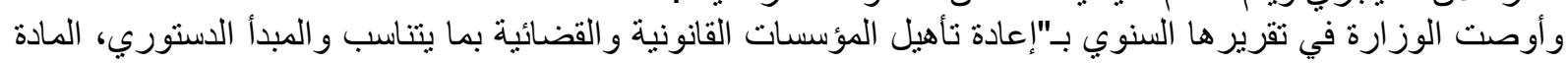

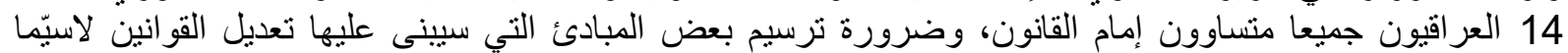
المساو اة و عدم التمييز بسبب الجنس" (84 جريمة غسل عار في 2009 عُرضت عشرة لئرة منهم على المحاكم، 2010).

المطلب الأول

المعالجة القانونية للقتل غسلا للعار 


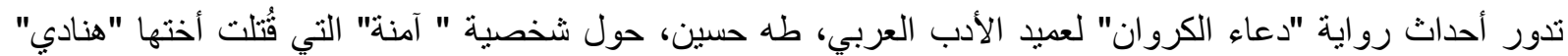

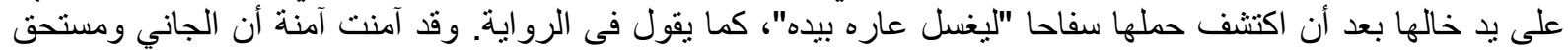

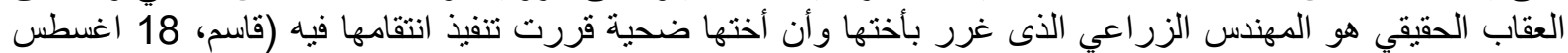

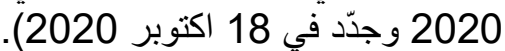

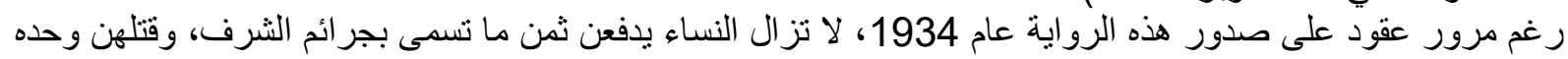
هو ما يحفظ "شرف" العزائلة.

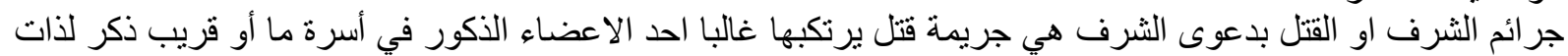

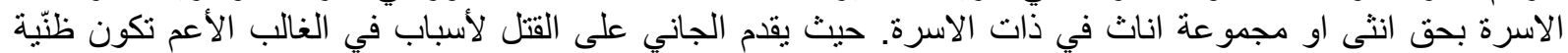

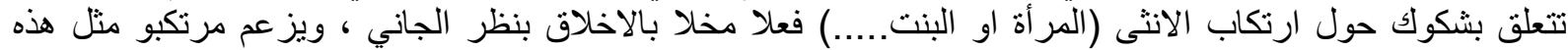

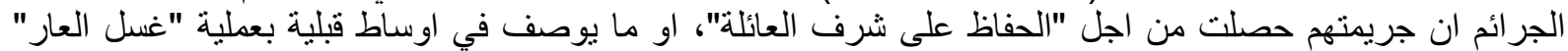

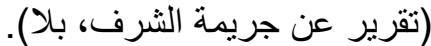

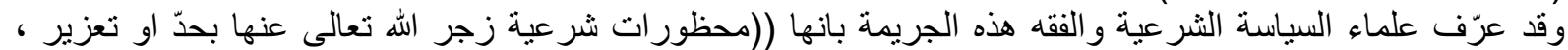
ولها عند التهمة حال استبراء تقتضيه السياسة الدينية ، ولها عند ثبوتها وصحتها حال الهال استيفاء توجبه الاحكام الثرعية))

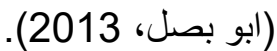

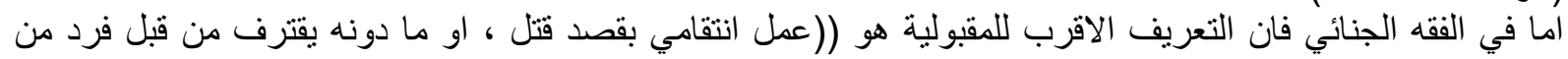

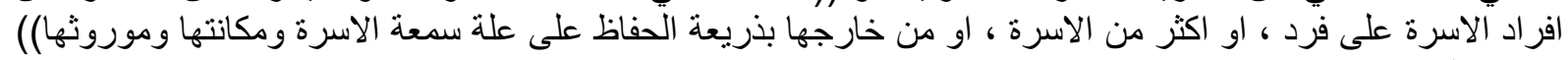

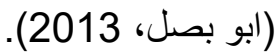

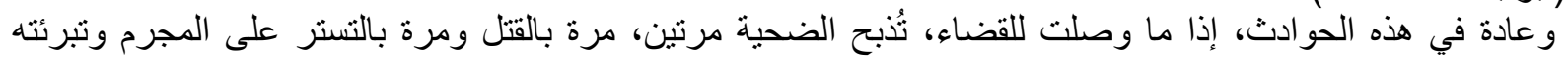

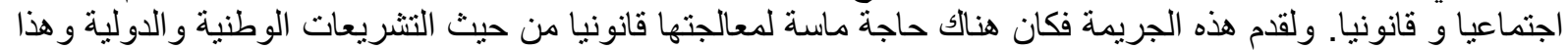
ما سنبحثه في فرعين نخصص الأول للمعالجة القانونية في التشريعات الوطنية و الثاني للمعالجة القانونية في الاتفاقيات

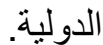

الفرع الأول: معالجة الجريمة في التثريعات الوطنية

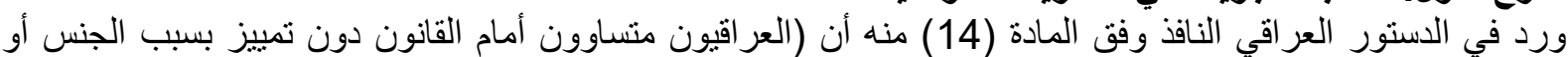

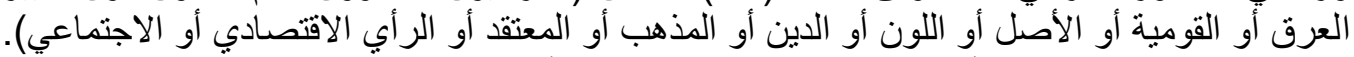

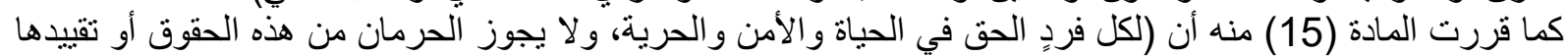

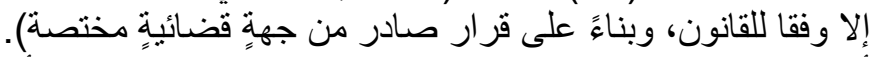

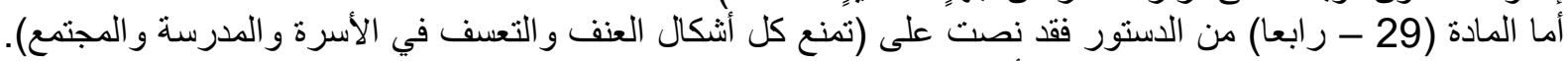

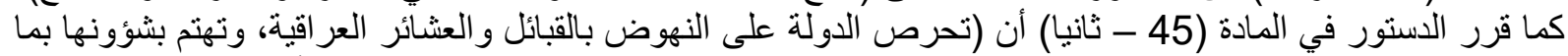

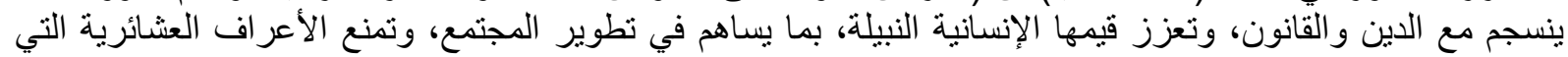
تنتافي مع حقوق الإنسان).

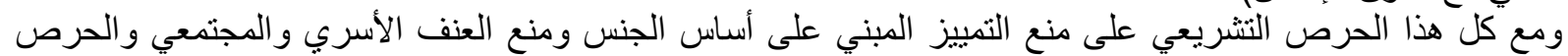

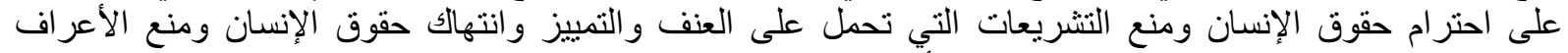

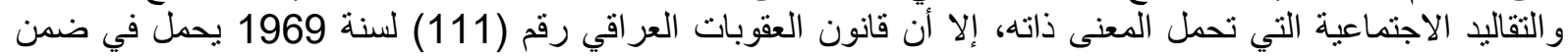

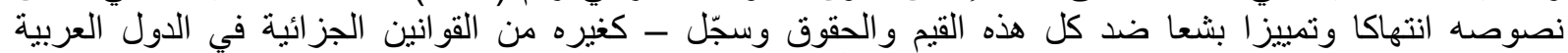

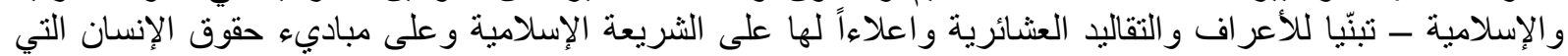

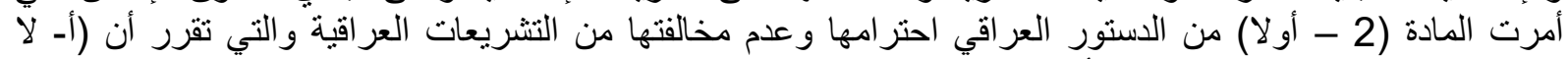

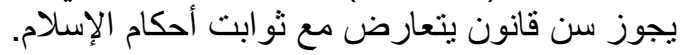

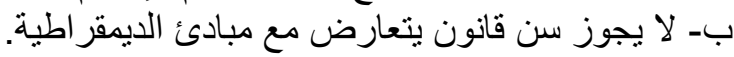

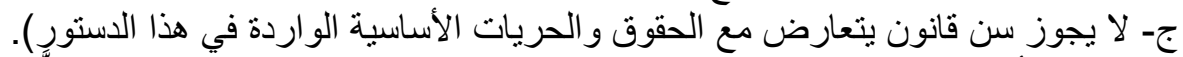

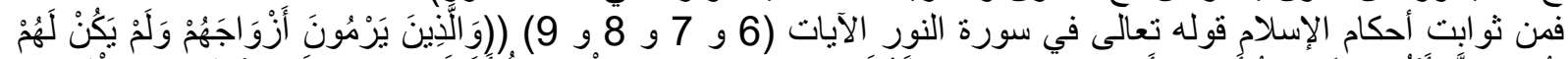

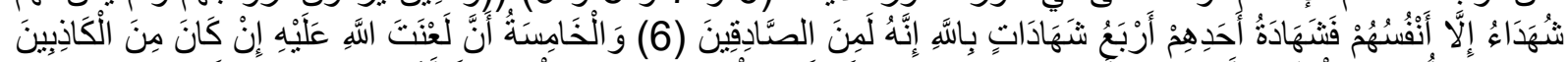

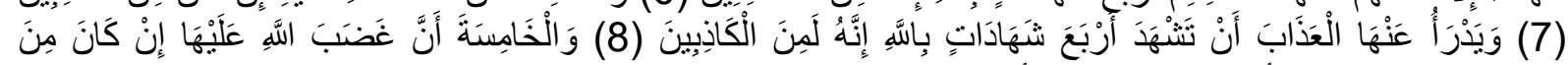

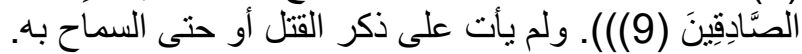

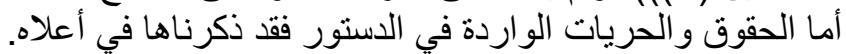

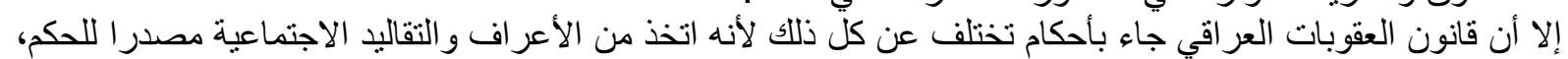
و هذا الأمر غير وانون العوبات في مصنادر التشريع. فالمادة ( 409) من قانون العقوبات العر اقي تنص على على جريمة القتل عند المفاجأة بالزنا:- 


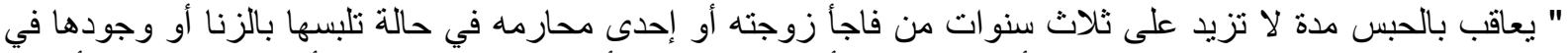

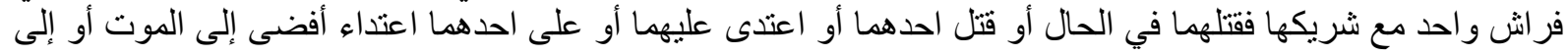

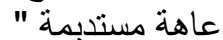

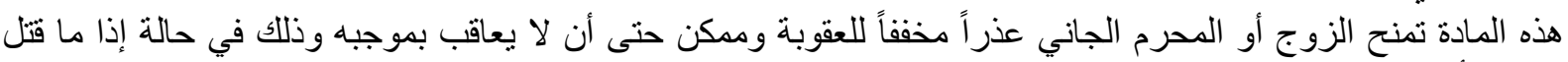

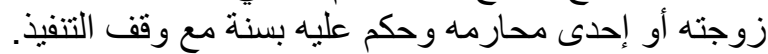

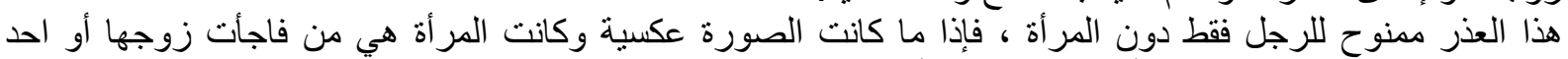

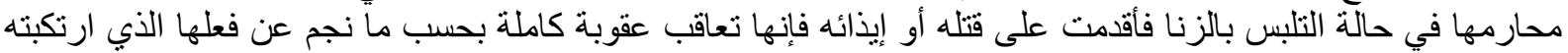

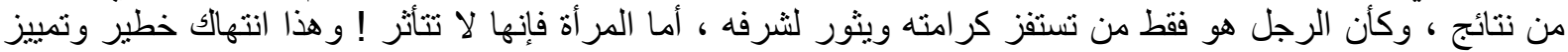

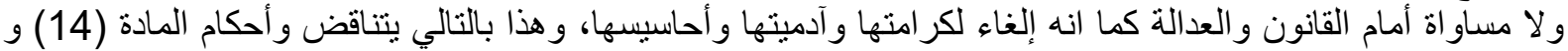

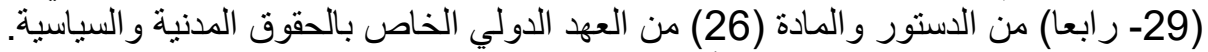

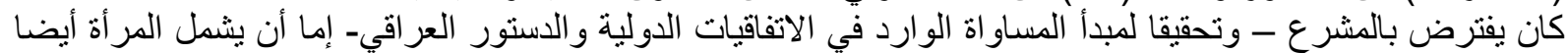

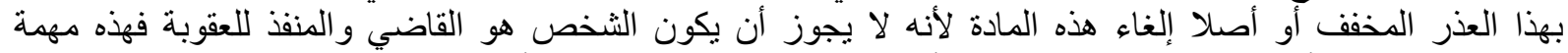

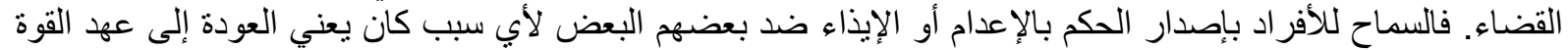

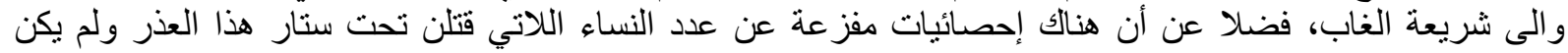

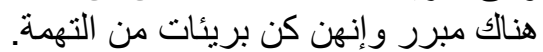

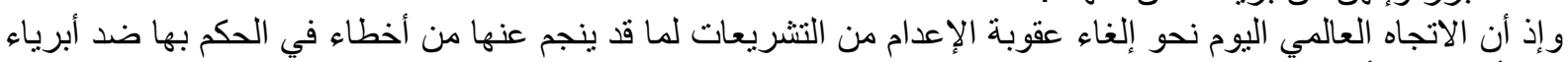

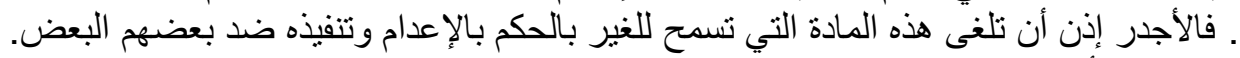

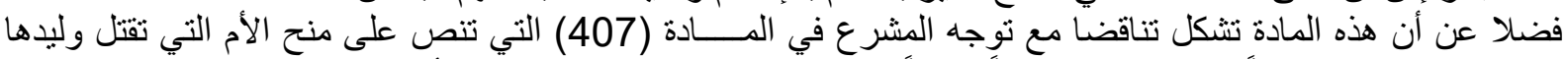

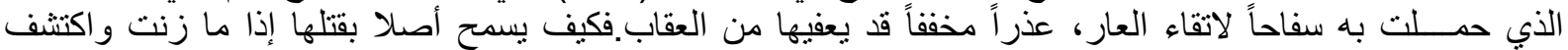

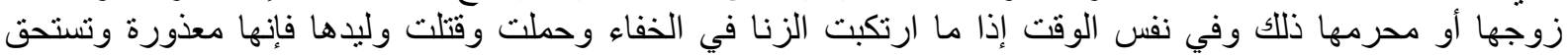
تخفيف العقاب عنها، و هذا تناقض تضاف تشريعي.

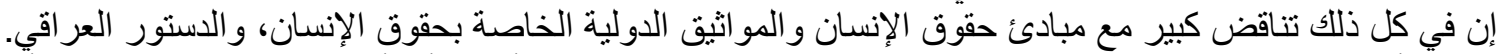

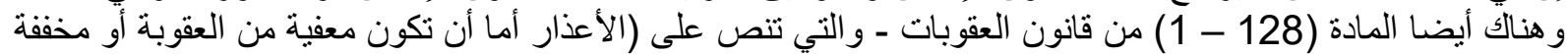

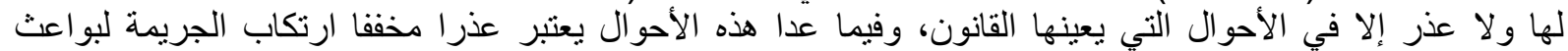

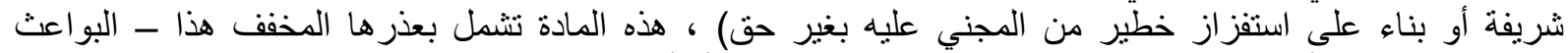

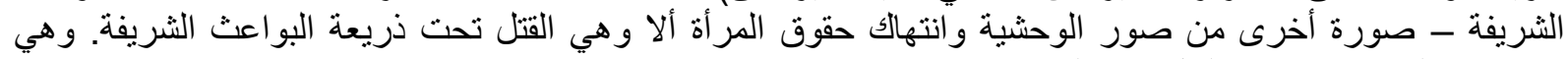

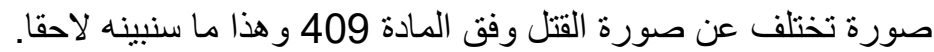

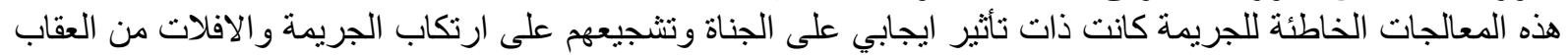

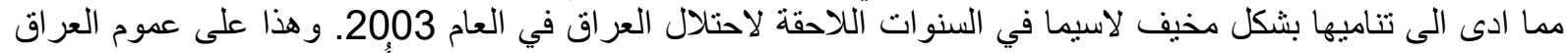

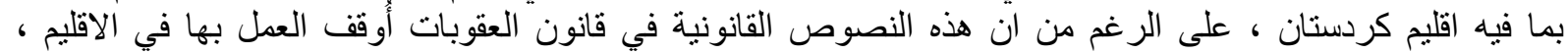

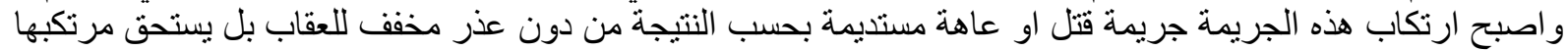

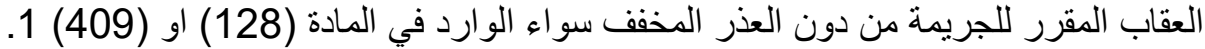

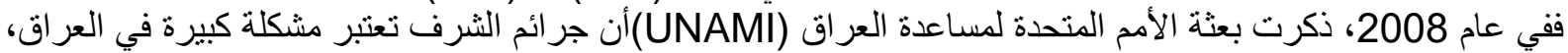

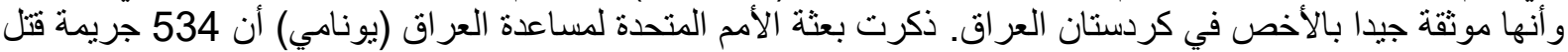

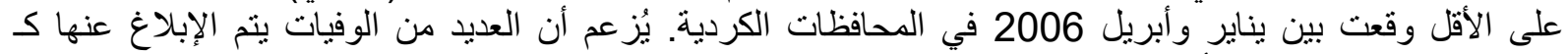

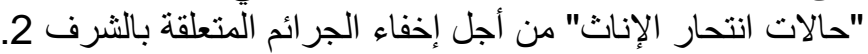

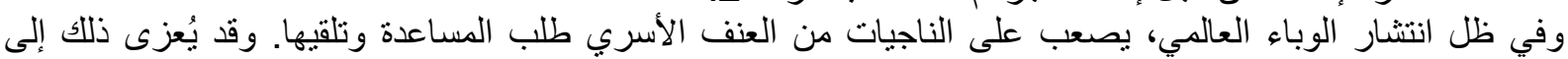

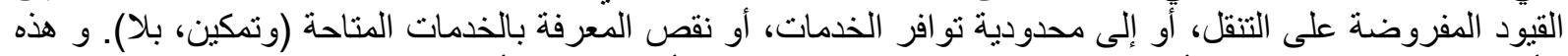

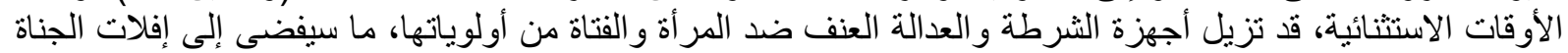
من العقاب. وينطبق ذلك بشكل خاص على المنطقة العربية، حيث تمتنع غالبية الدول عن تجريم العنف الأسري (وتمكين،

الفرع الثاني: معالجة الجريمة في المواثيق الدولية

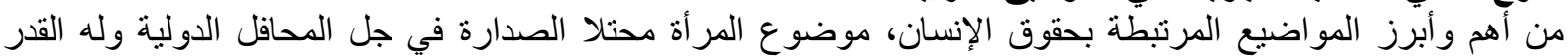

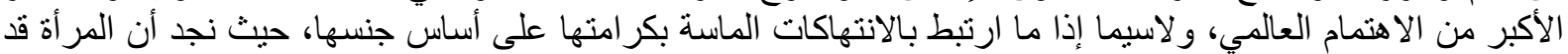

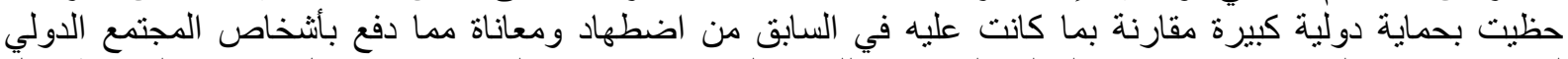

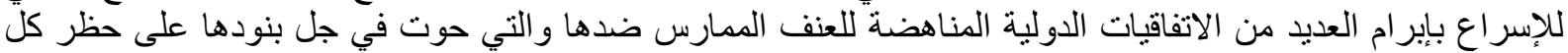


الأفعال التي من شأنها أن تحط من إنسانيتها أو تمس بأي حق من حقوقها المنصوص عليها في بنودها المصادق عليها

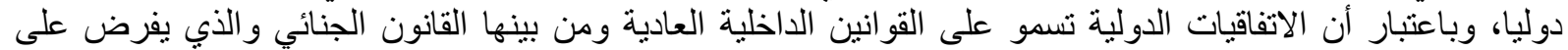

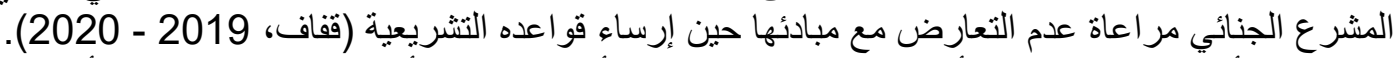

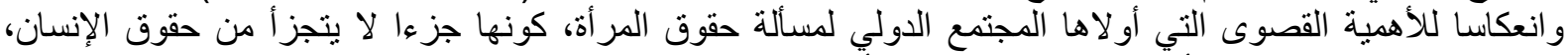

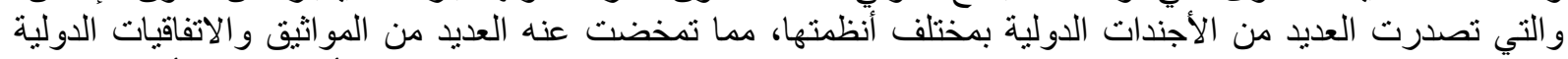

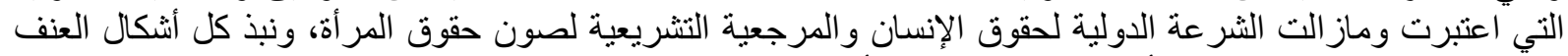

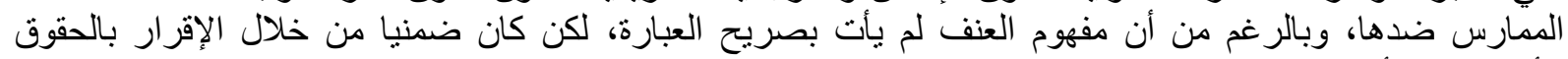
الأساسية للمر أة ونبذ التمييز ضدهار التها (قفاف، 2019 - 2020).

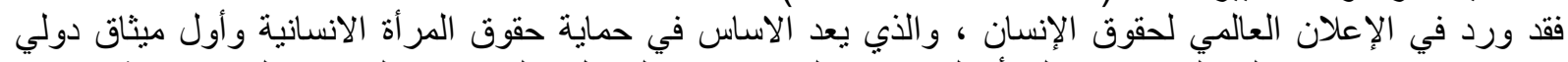

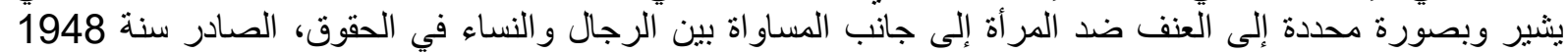

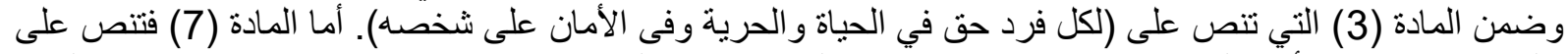

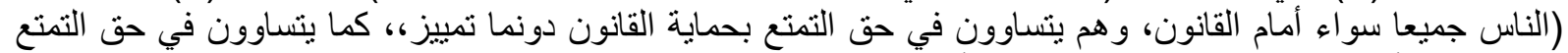

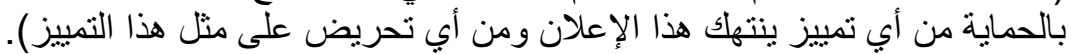

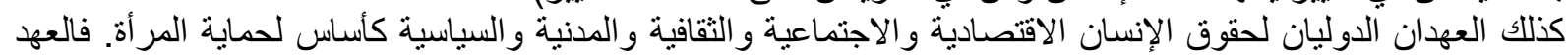

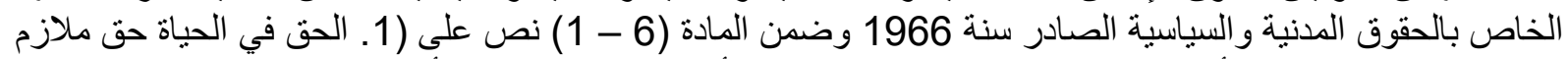

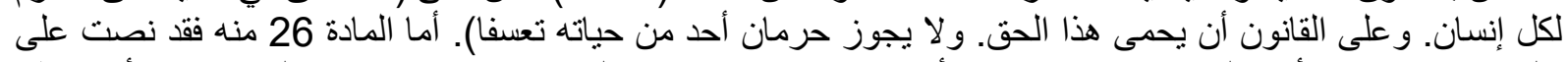

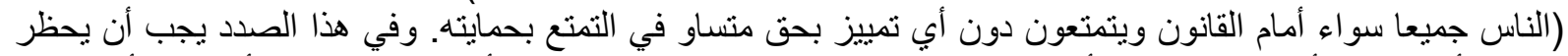

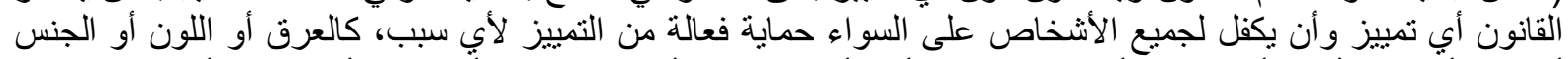

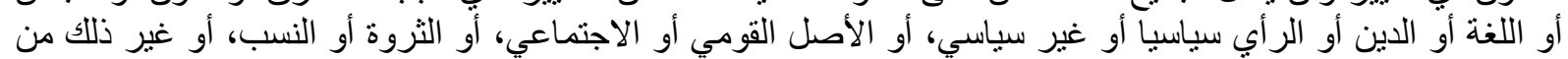

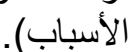

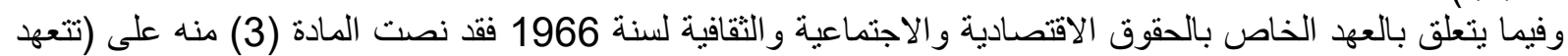
الدول الأطراف في هذا العهد بضمان مساواة الذكور و الإناث في حق التمتع بجميع الحقوق الاقتصادية والاجتماعية و الثقافية المنصوص الفر في فيها في هذا العهد).

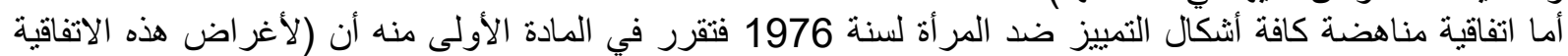

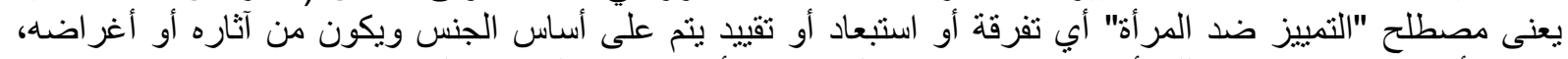

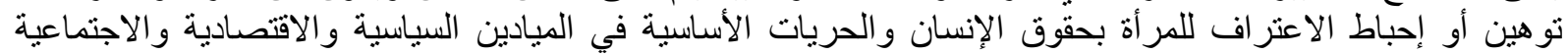

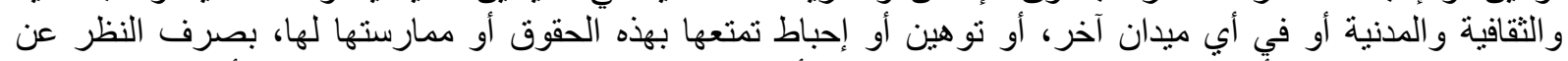

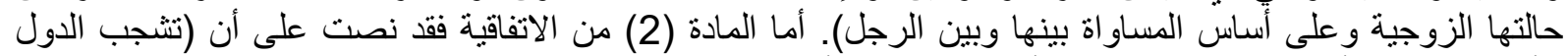

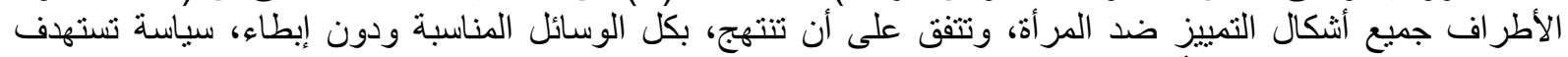

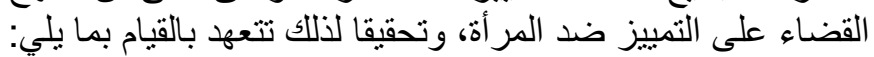

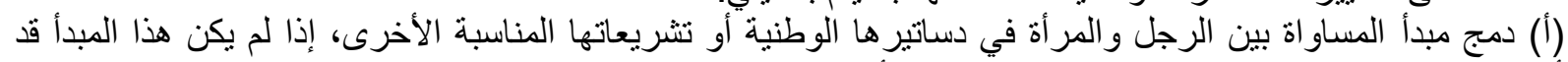

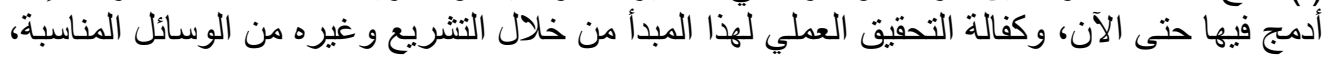

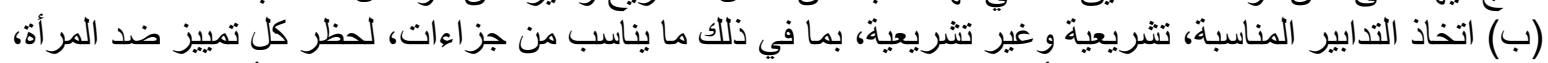

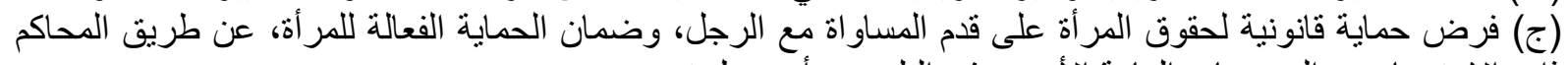

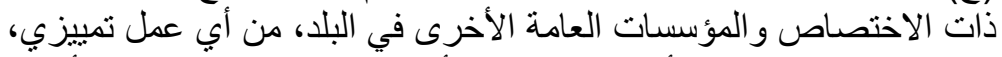

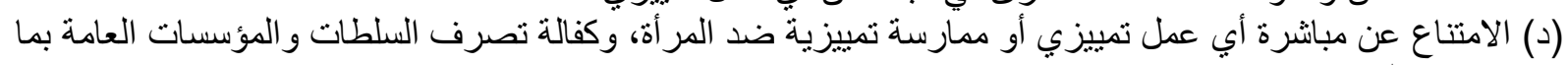

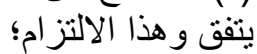

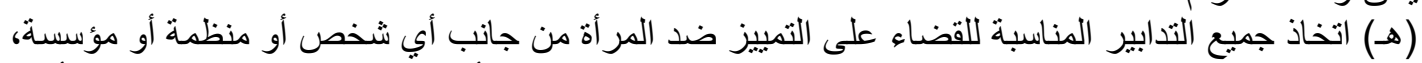

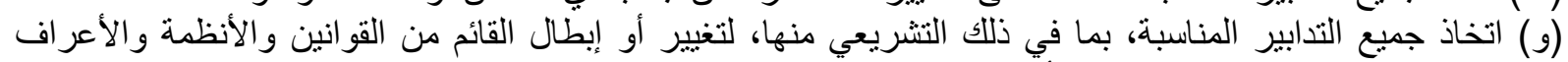

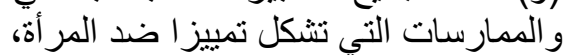

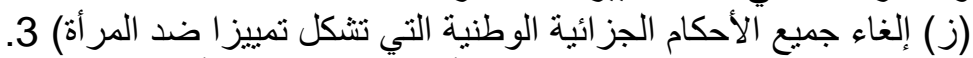

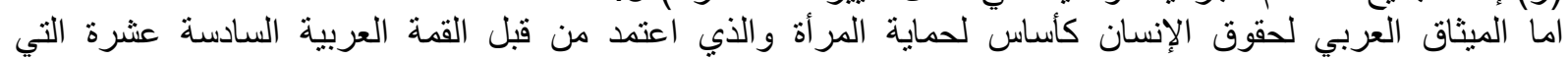

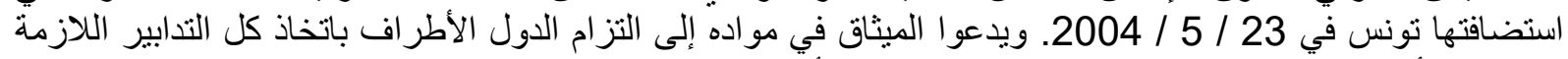

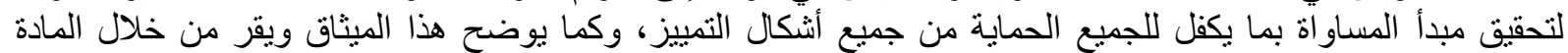

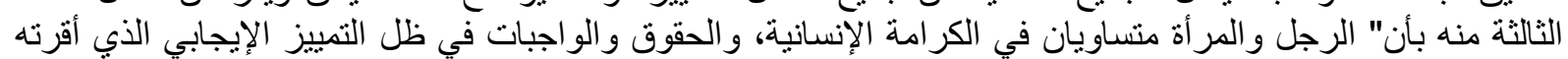

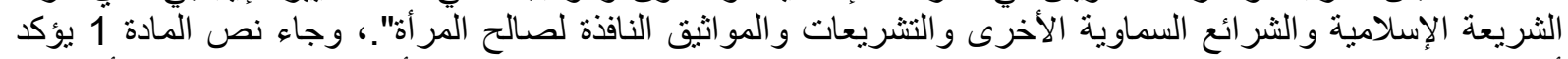

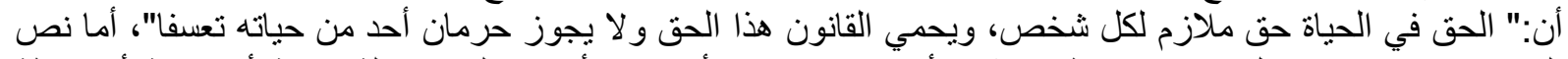

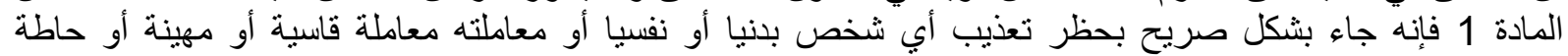

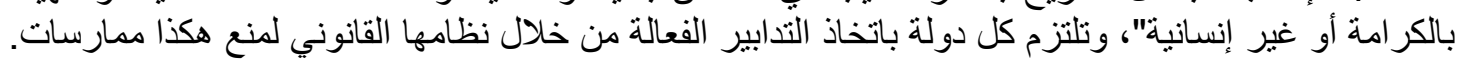


كما وصدر قرار عن الجمعية العامة للامم المتحدة بالرقم 55 / 66 بشأن العمل من أجل القضاء على الجر العيأم المرتكبة

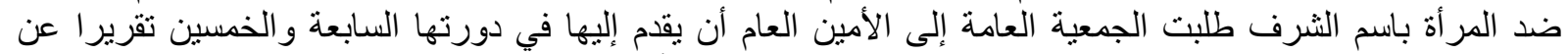

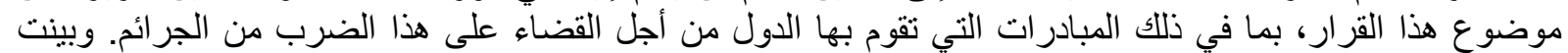

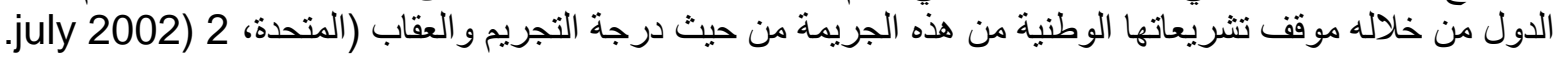

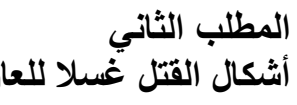

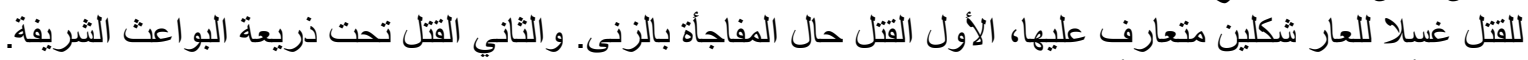

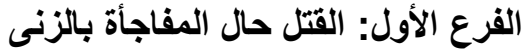

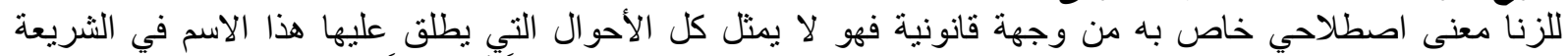

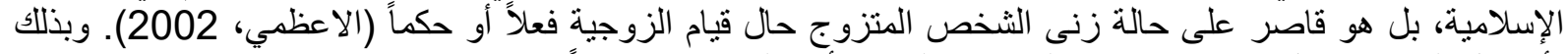

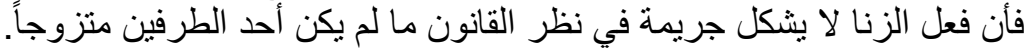

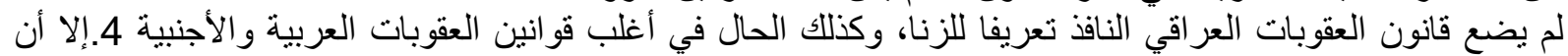

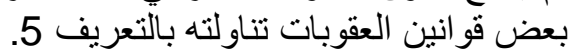

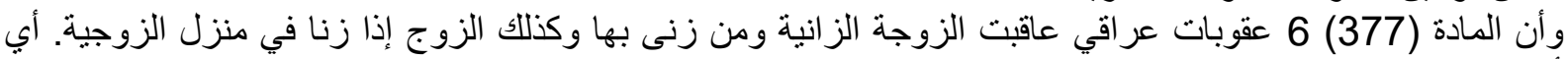

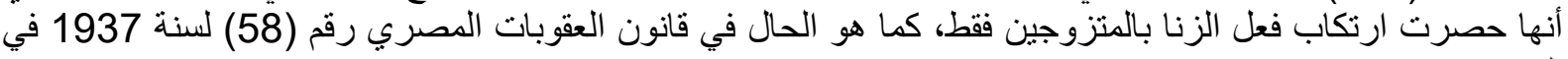

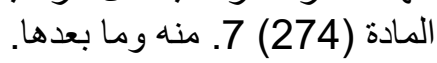

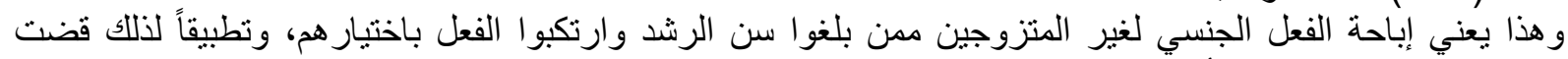

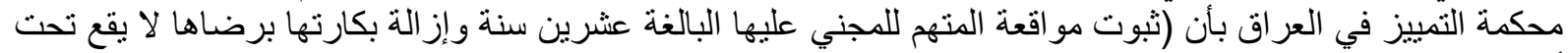
أي نص عقابي ويلزم الحكم ببر اءته) 8.

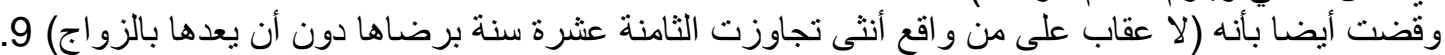

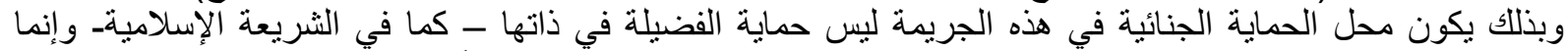

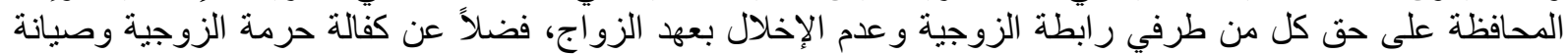

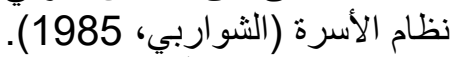
عناصر هذه الجريمة هي (النواري،

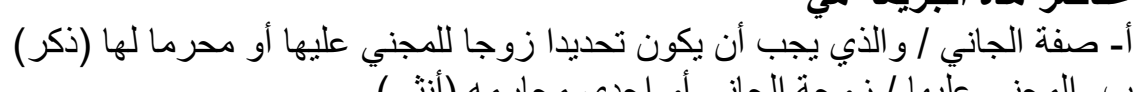

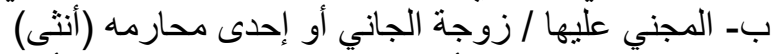

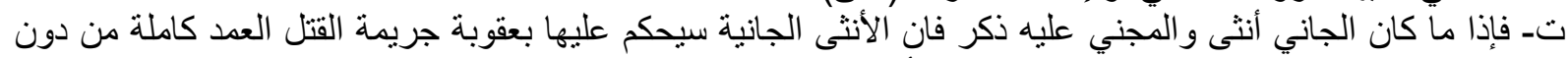

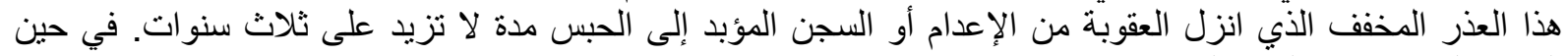

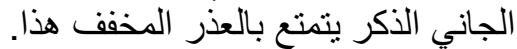

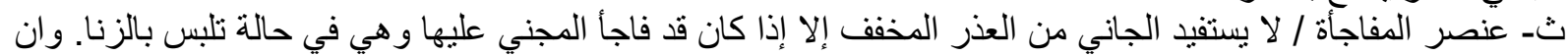
يكون هذا التلبس بالزنا مفاجئا للجاني، عندما لم يكن منوقعا على الإطلاق فعل المجني عليها. أو انه كان يثلك - غير التير متيقن - من قيامها بالزنا.

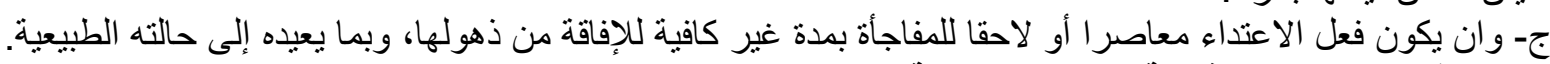

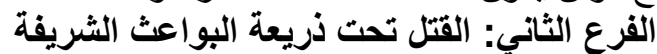

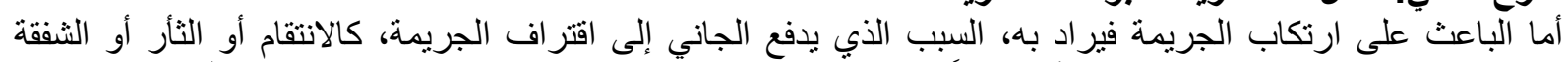

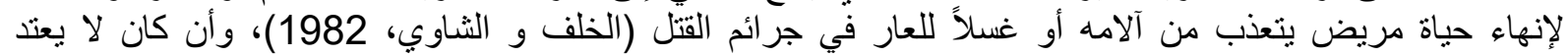

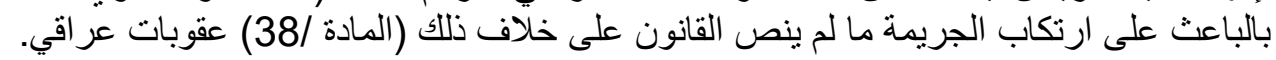

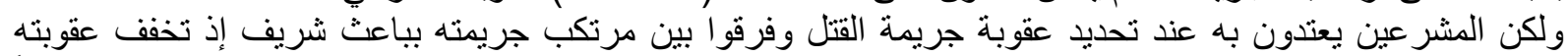

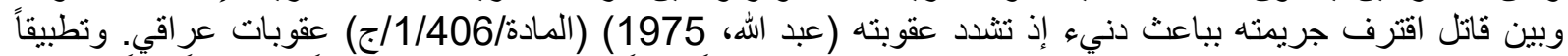

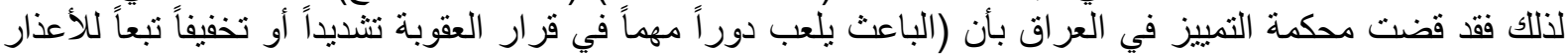
القانونية والظروف القضائية المقررة في القانون) 10 الفئن

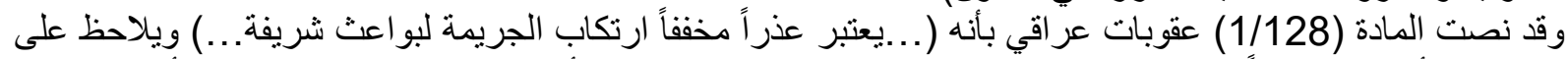

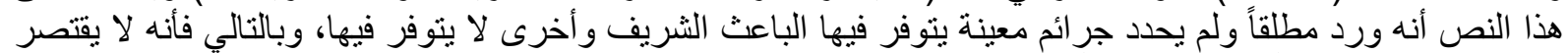

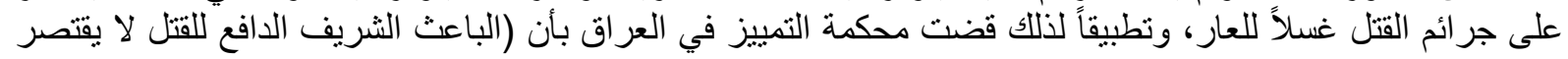


على جر ائم القتل غسلاً للعار فقط لعدم وجود نص قانوني بذللك و إنما يشمل حالة قتل الثرطي للسجين الذي هرب أثناء

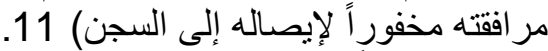
أن القتل غسلاً للعار هو لإِلَ الإنسان زوجته أو إحدى محارمه أو أقاربه تطهيراً لكل ما يلحق به من السب أو العيب

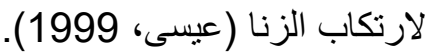

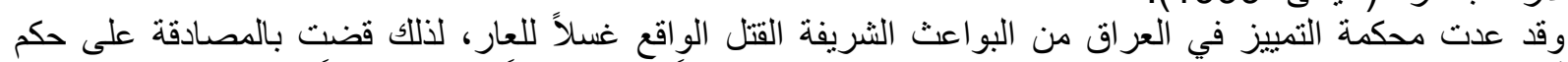

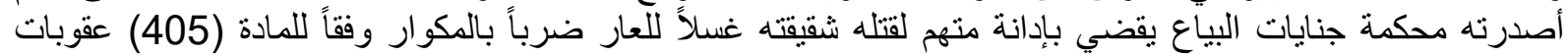

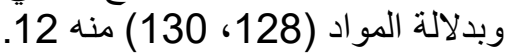

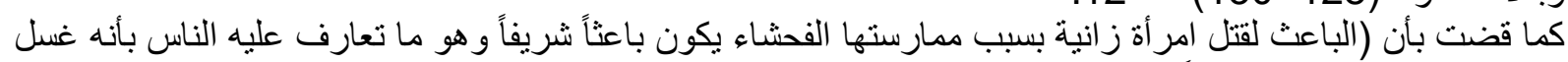

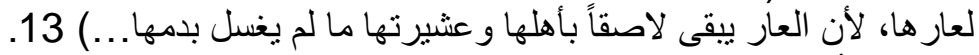

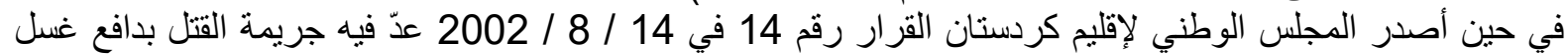

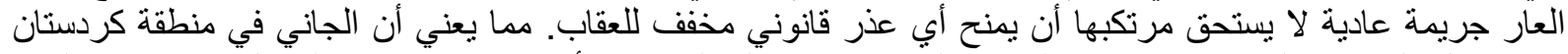

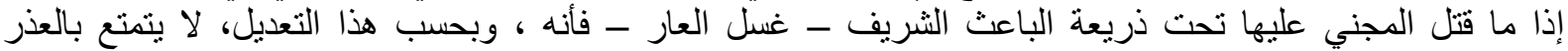

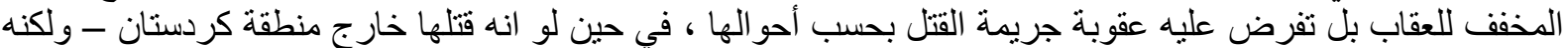

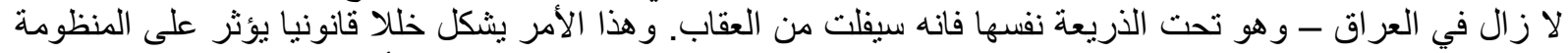

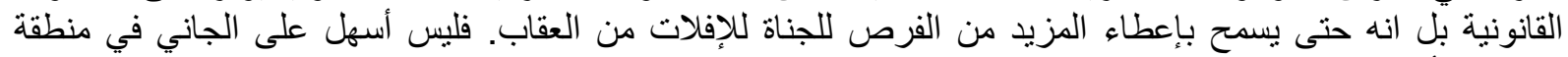

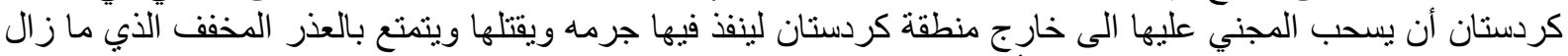

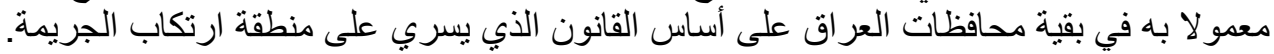

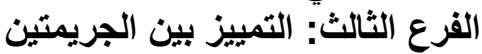
هذا وأن التمييز بين القتل حال المفاجئة بالزنى و القتل بين بياعث شريف يكون من وجوه عديدة أهمها: أولاً: من حيث الطبيعة القانونية:

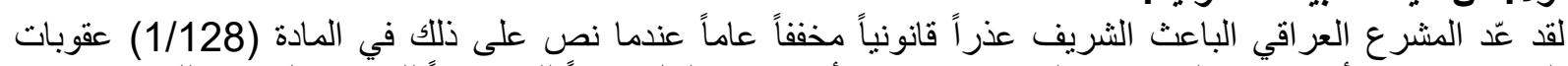

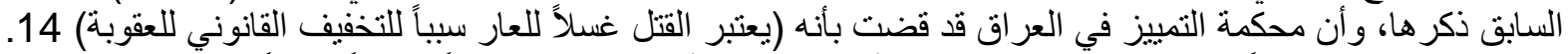

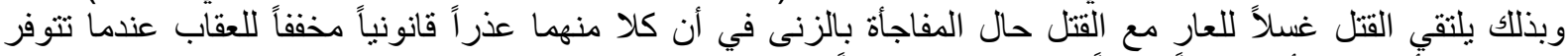

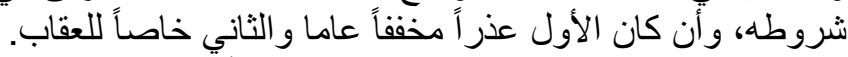

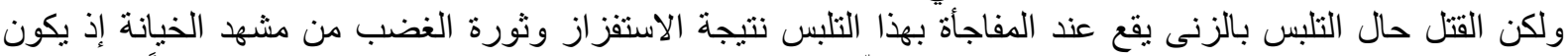

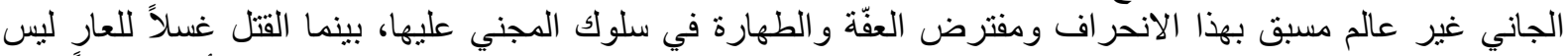

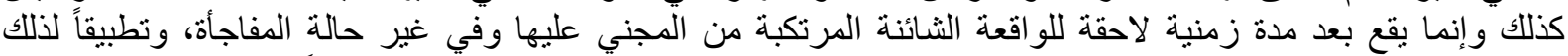

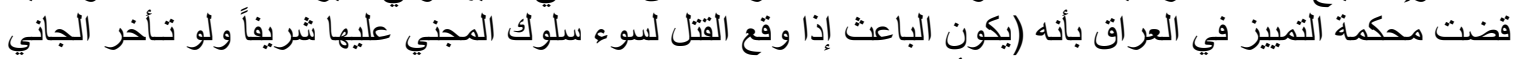

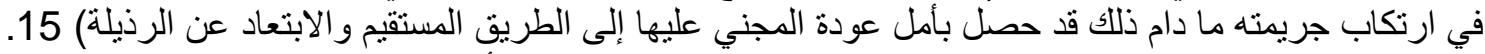

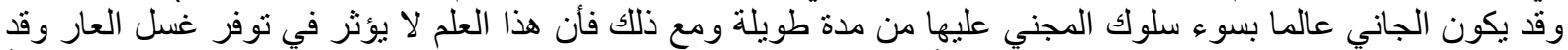

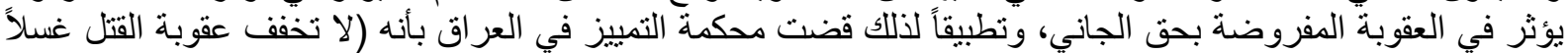

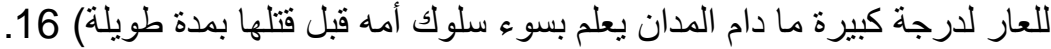

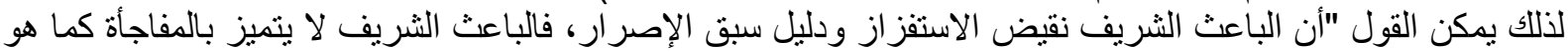

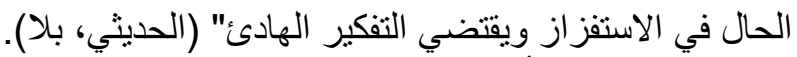

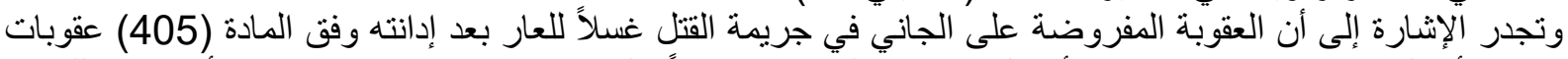

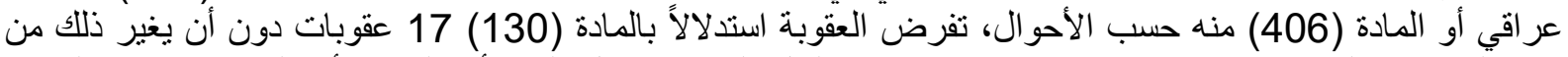

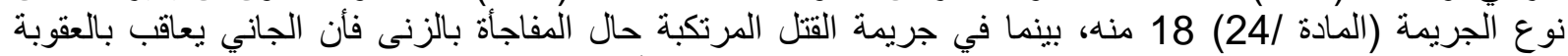

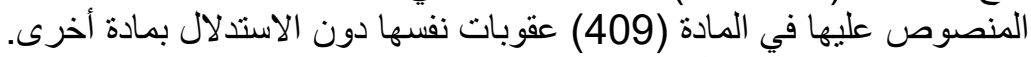

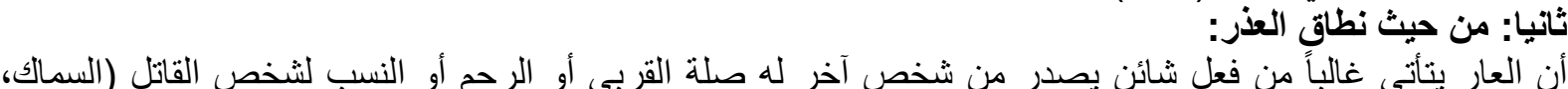

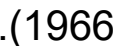
لذلك يمكن القول أن العذر المخفف في الباعث الثريف عند القتل غسلاً للعار يتوسع نطاقه ليشمل الاقارب من النساء

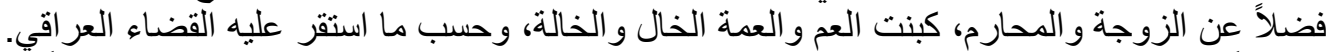

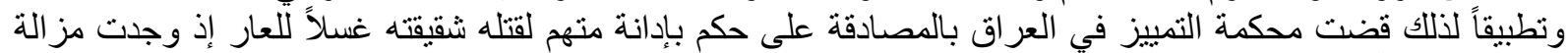

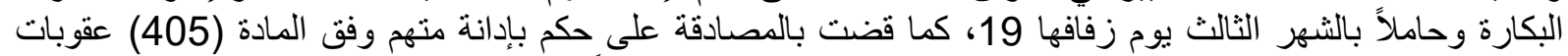

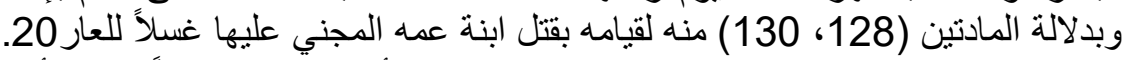

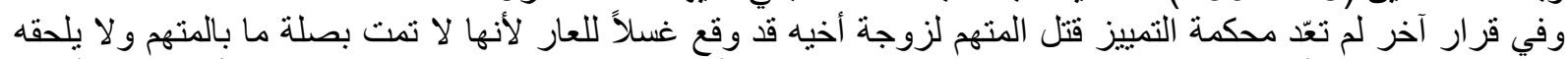

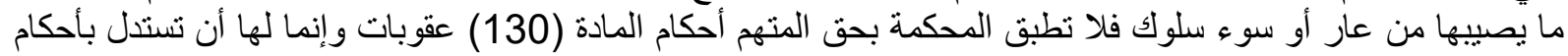

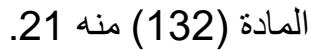


أما في حالة المفاجأة بالزنى فأن نص المادة (409) عقوبات يقتصر انطباقه على قتل الزوجة أو إحدى المحارم فقط ولا

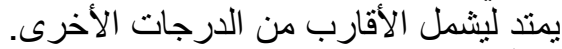

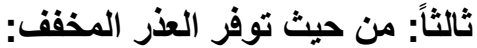

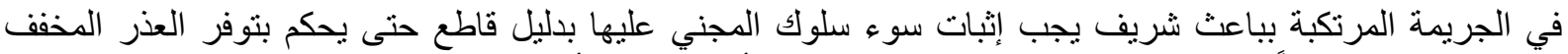

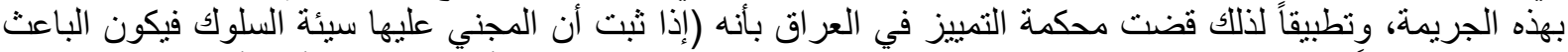

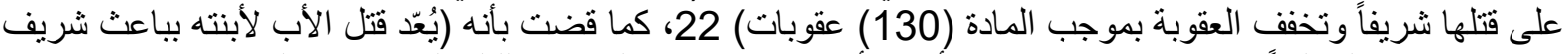

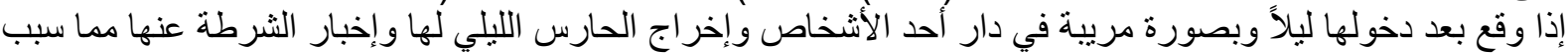

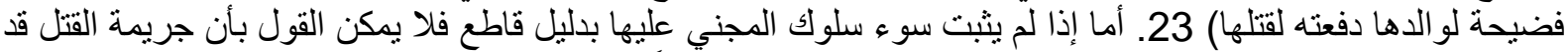

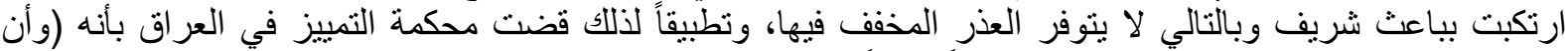

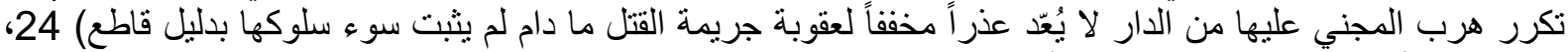

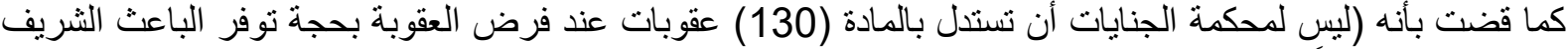

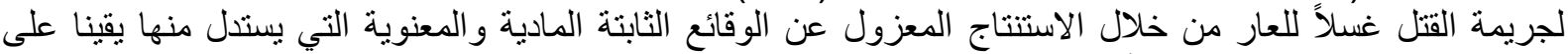

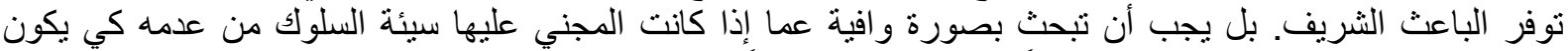

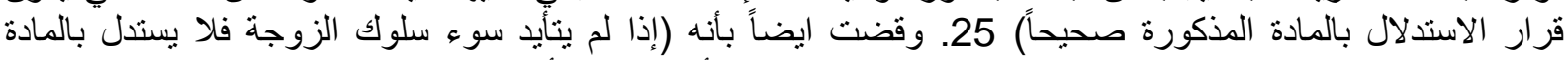

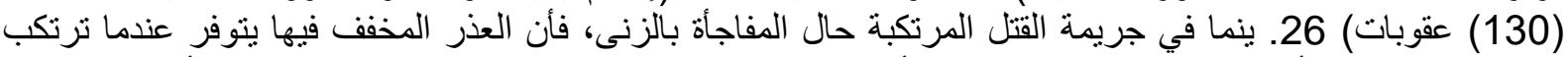

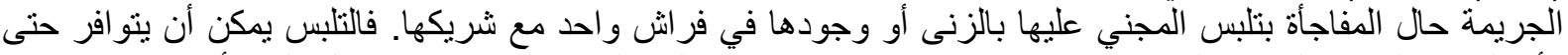

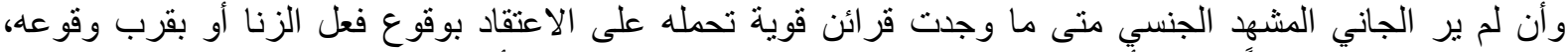

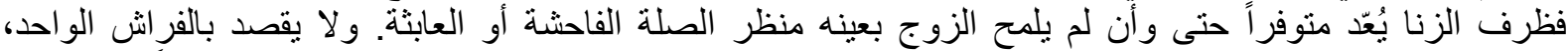

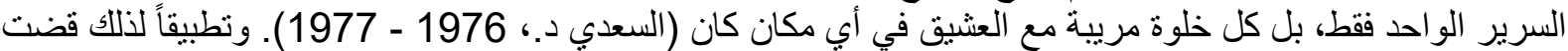

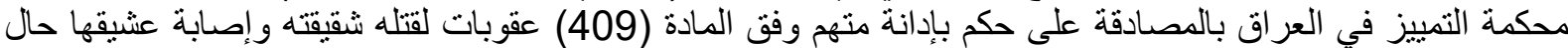

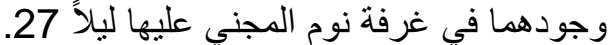

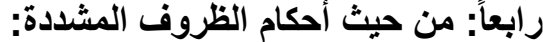

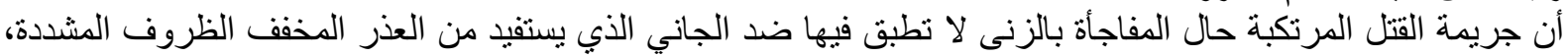

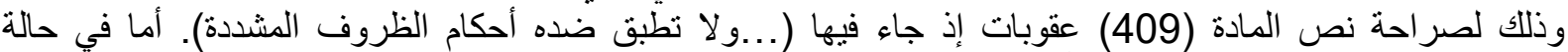

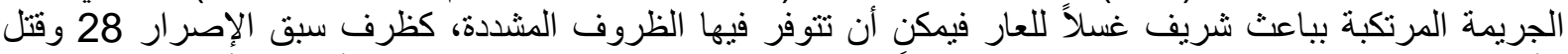

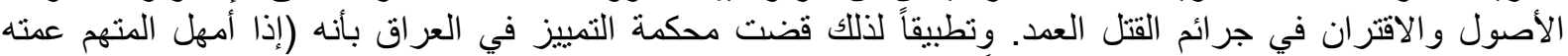

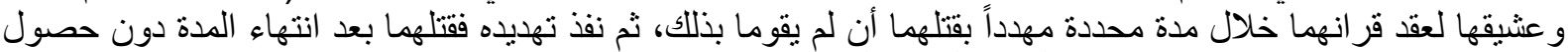

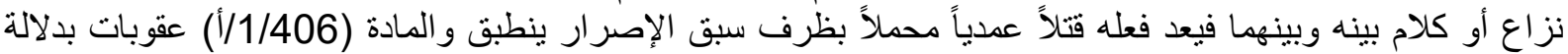
المادتين (128، 130 130 منداع) 29.

ويعد ظرف سبق الإصر ار منوفراً إذا صمم الجاني على جريمة القتل بباعث شريف غسلاً للعار قبل يوم و احد من تنفيذها.

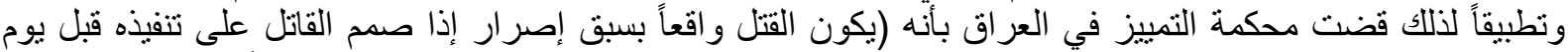

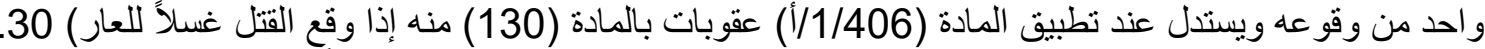

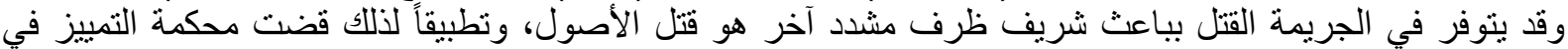

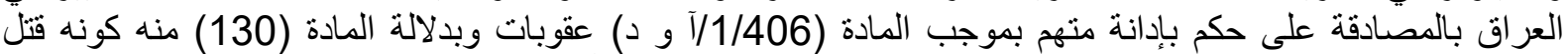

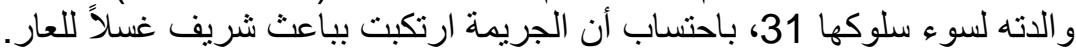

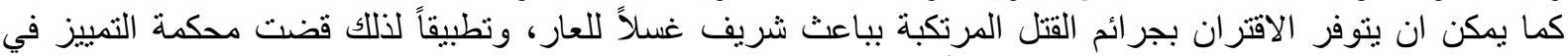

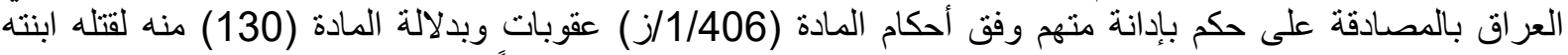

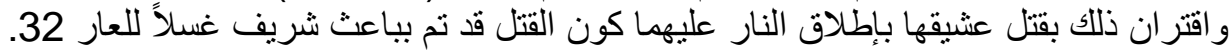

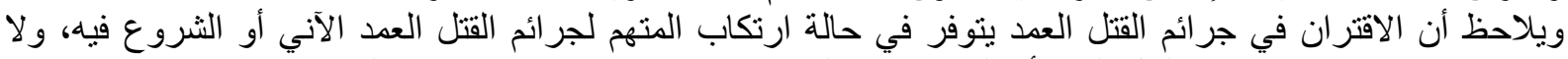

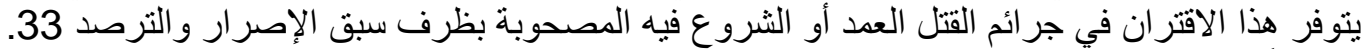

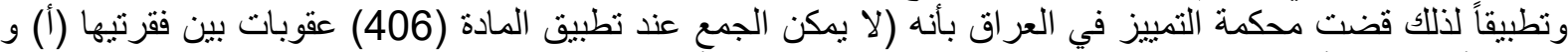

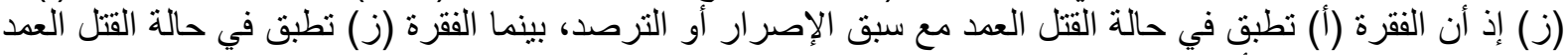

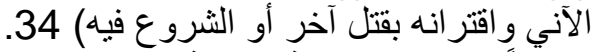

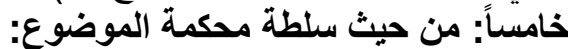

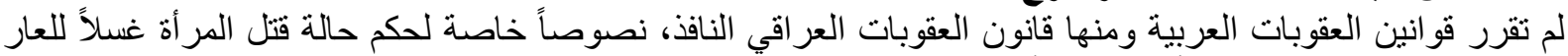

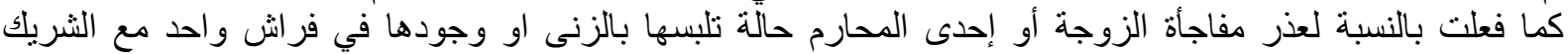




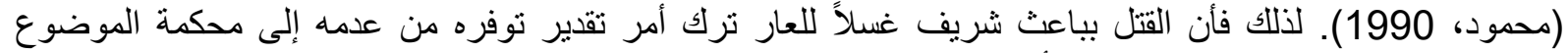

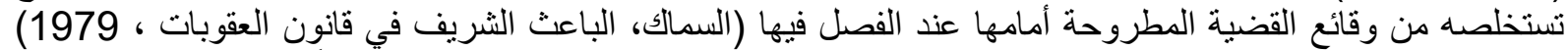

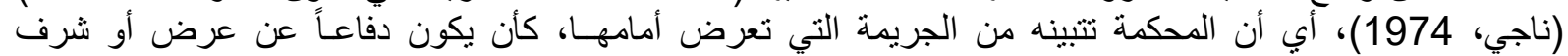

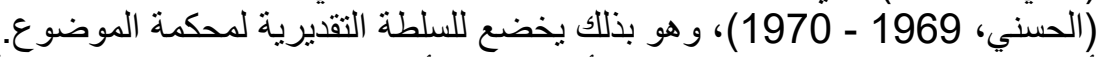

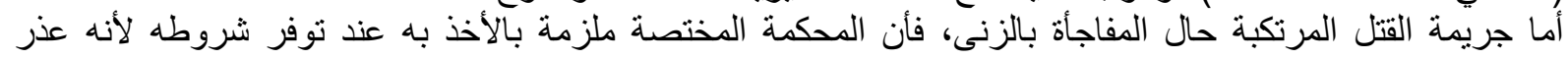

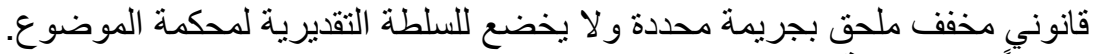

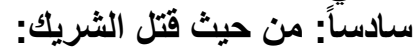

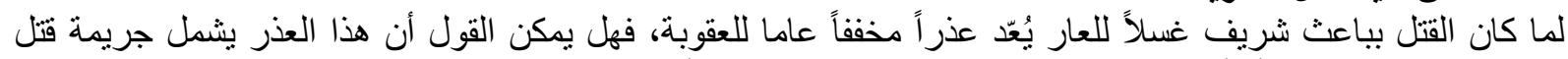

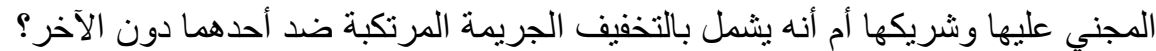

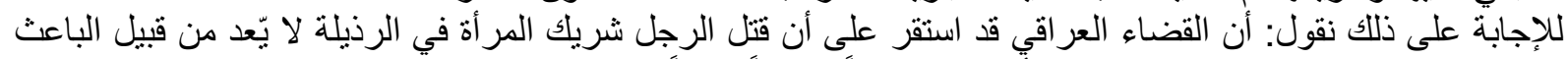

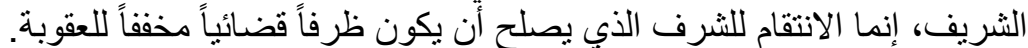

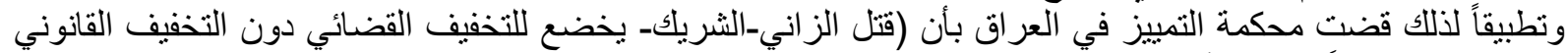

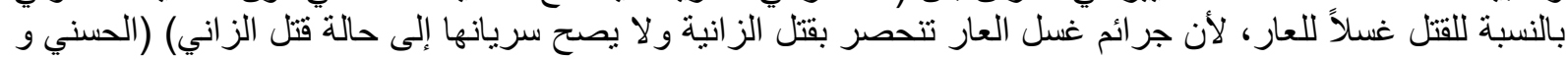

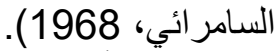
كما قضت بأنه (وجد أن المحكمة أخطأت في تطبيق القانون وذللك لأن الثابت من أوراق الدعوى بأن الثنان المنهم قد شاهد

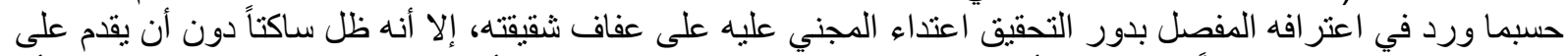

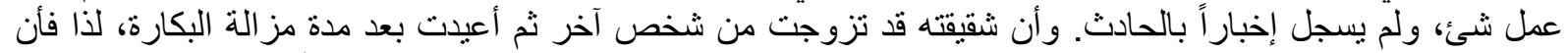

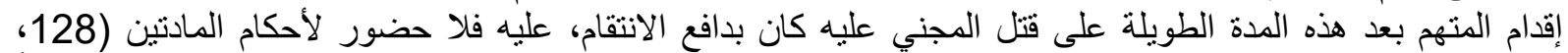

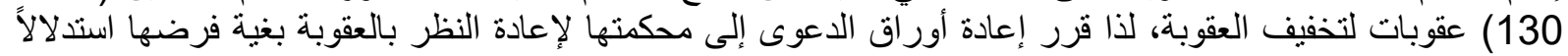
بالمادة (132) (132) عقوبات اتلفئ) (الكرباسي، 1999).

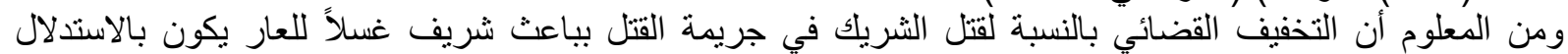

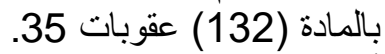

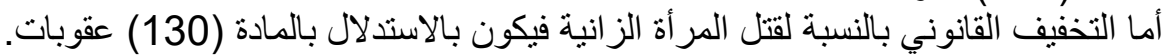

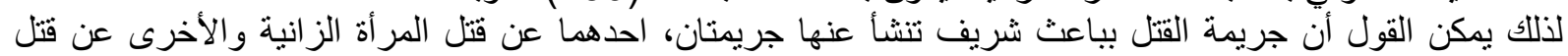

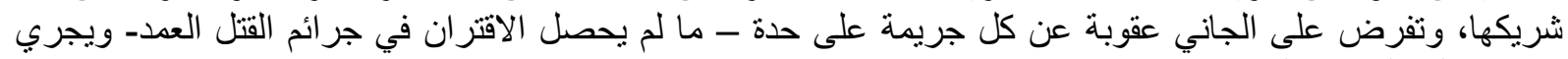
تنفيذها على الجاني بالتعاقب.

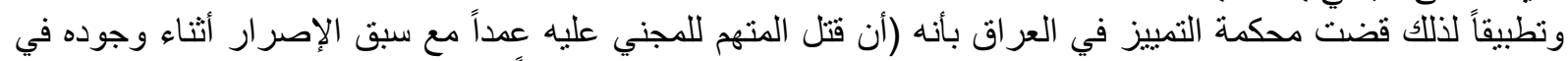

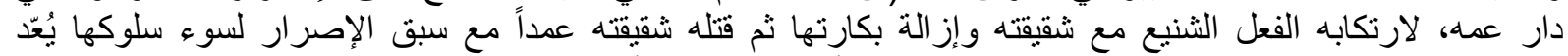

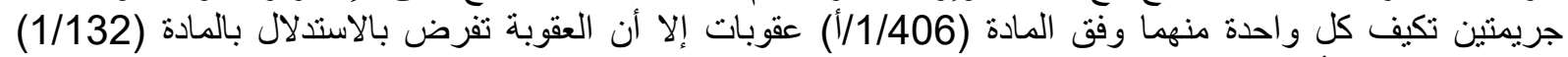

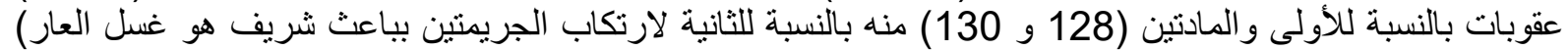

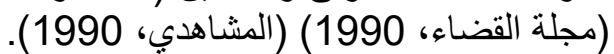

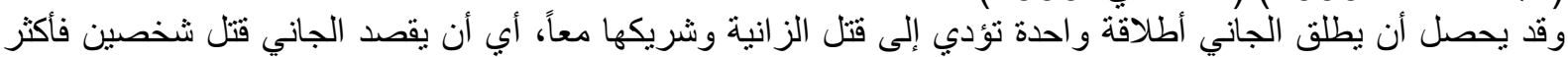

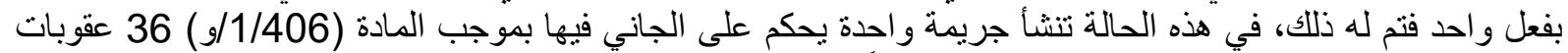

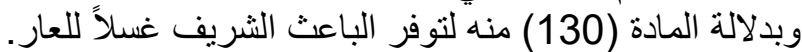

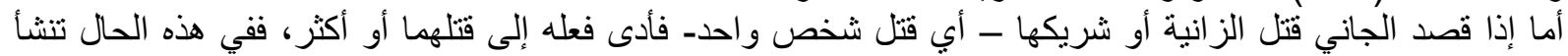

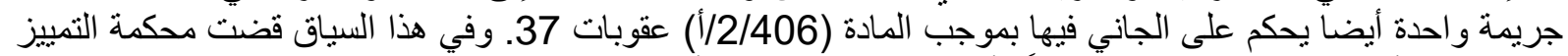

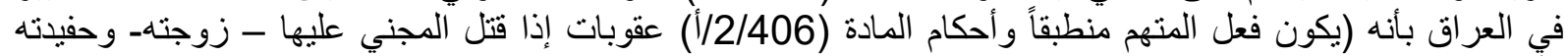

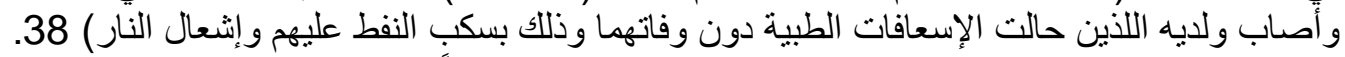

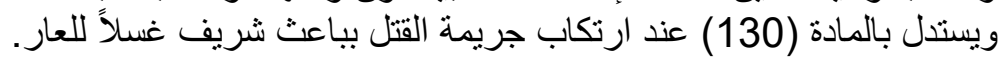

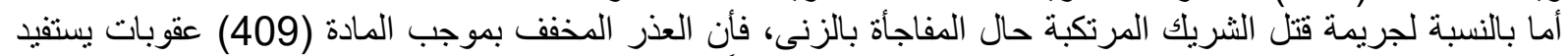

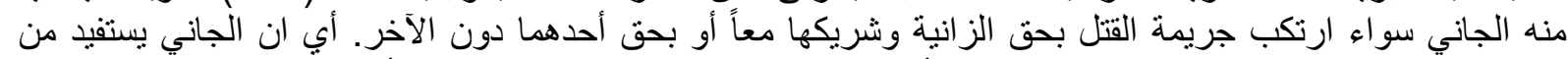

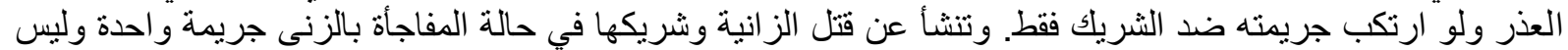
جريمتان. سابعاً: من حيث صفة الجاني وان وان المجني عليه:

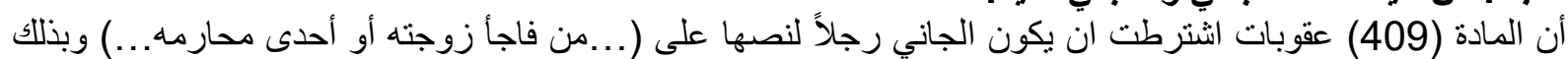

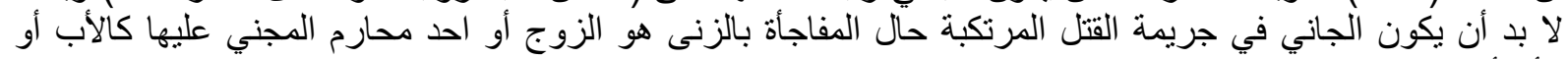

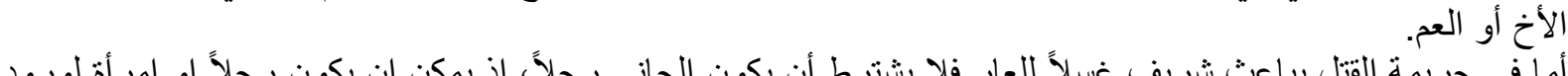

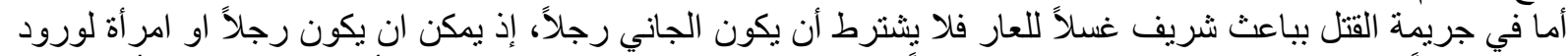

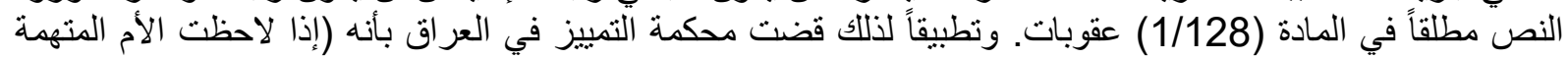




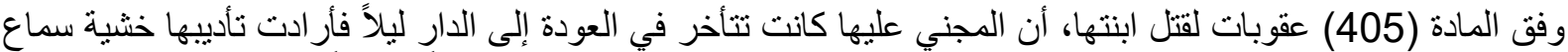

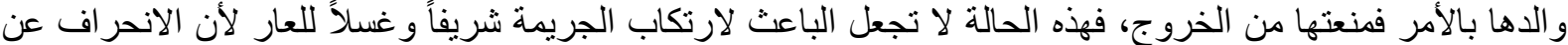

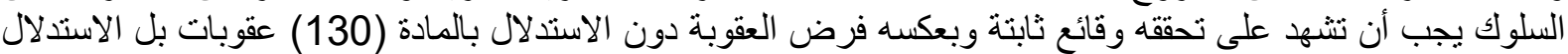

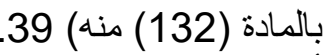

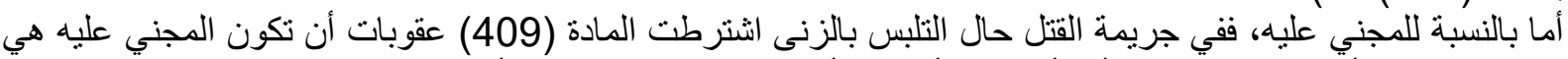

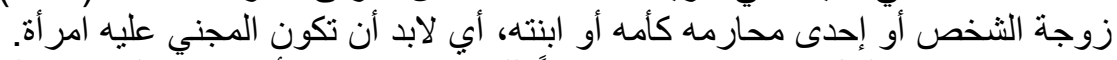

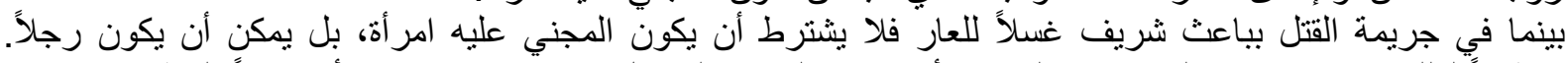

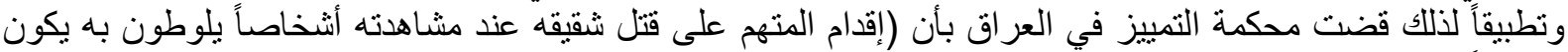

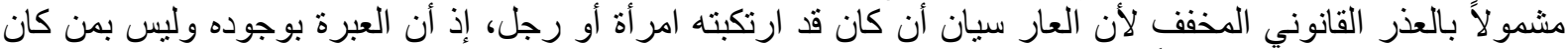

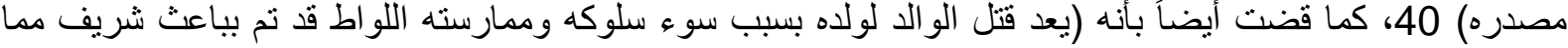

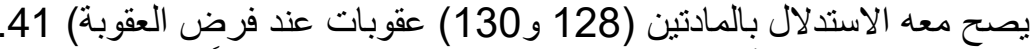

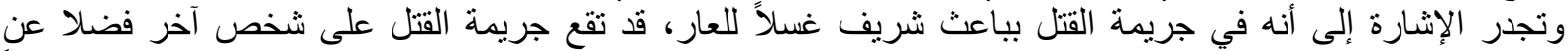

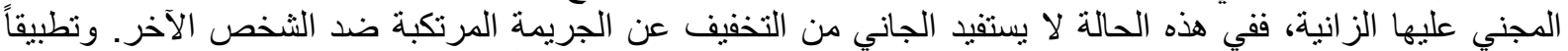

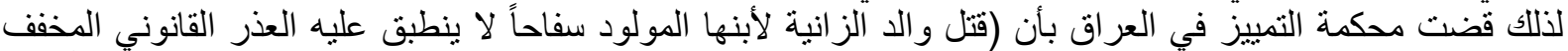

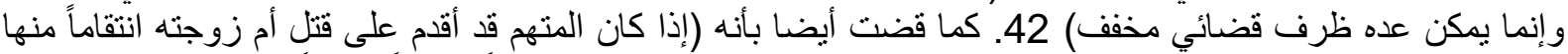

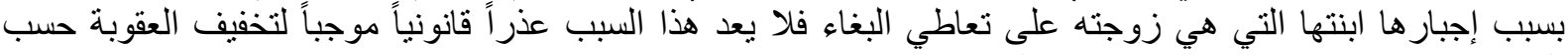

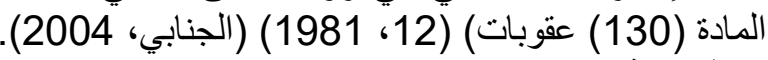
المطلب الثالث

دور منظمات المجتمع المدني في التصدي للجريمة

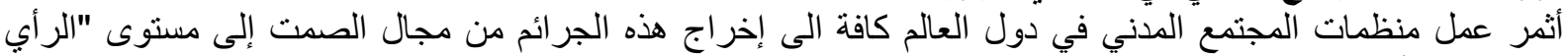

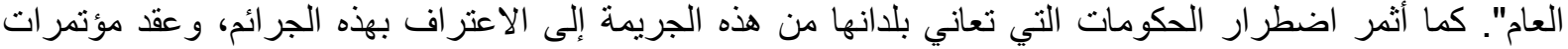

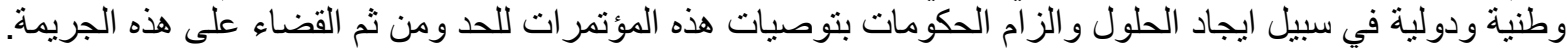

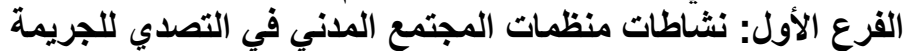

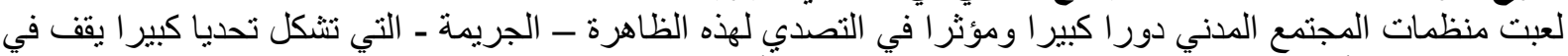

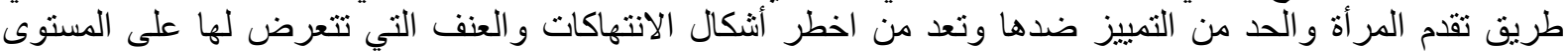

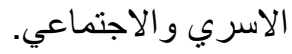

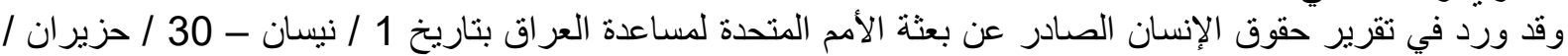

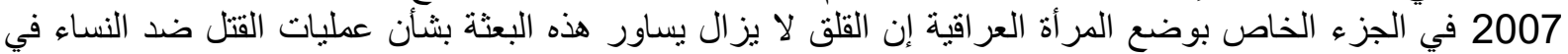

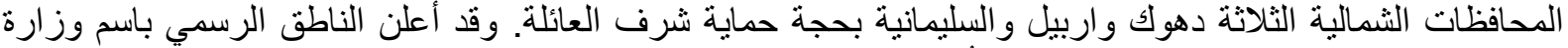

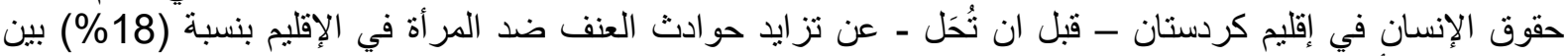

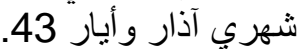

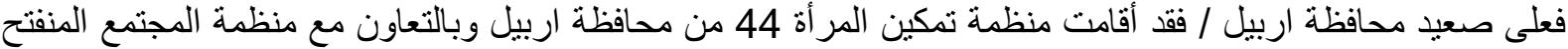

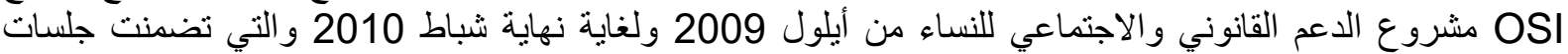

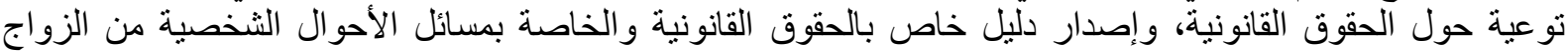

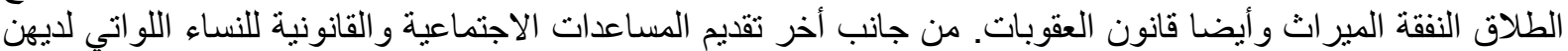

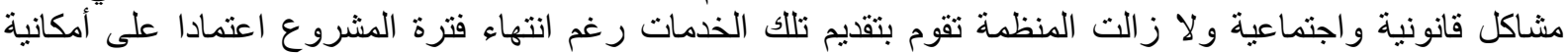

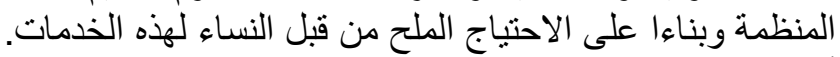

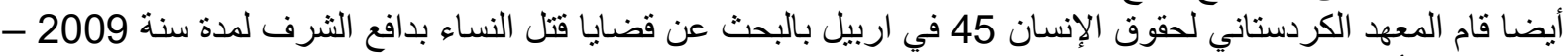

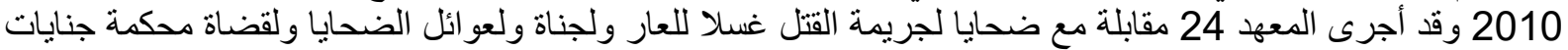

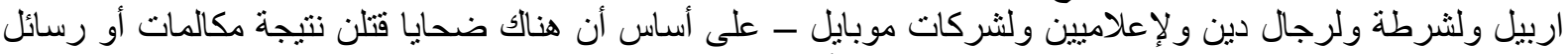

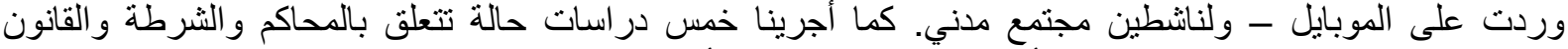

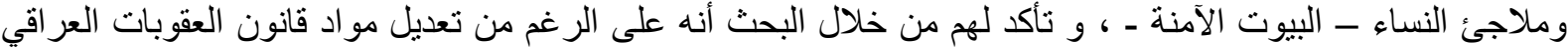

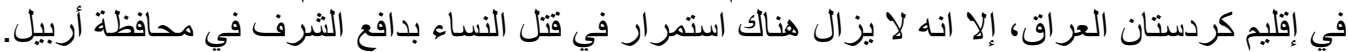

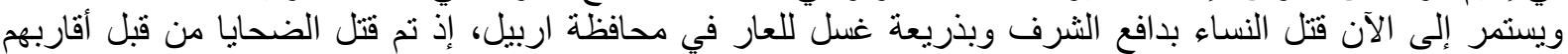

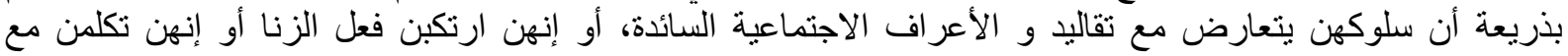


أثخاص من خارج نطاق العائلة أو إنهن نزوجن من دون رضا العائلة أو شوهدوا برفقة أشخاص غرباء ليسوا من

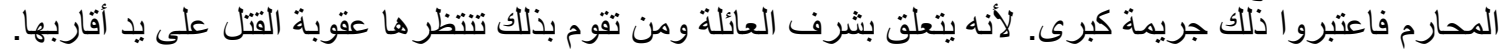

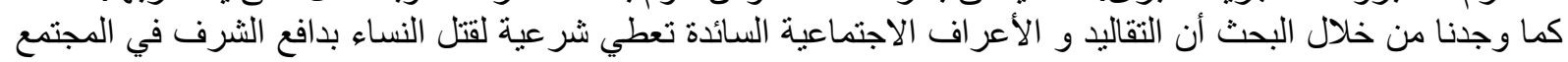
الكردي. أيضا من الناحية القانونية في إقليم كردستان العراق هنالك محاو لات للتقليل من ظاهرة قتل النساء بدافع الثرف فتم فت تعديل

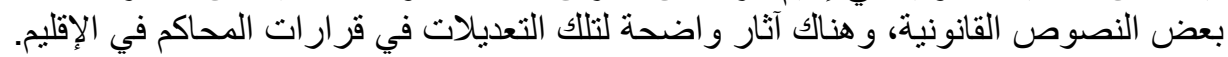

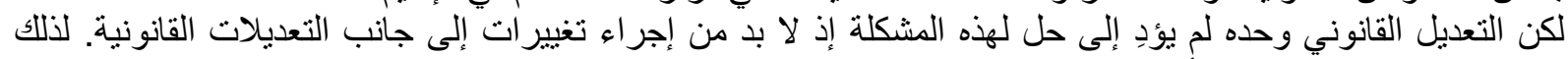

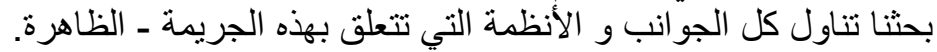

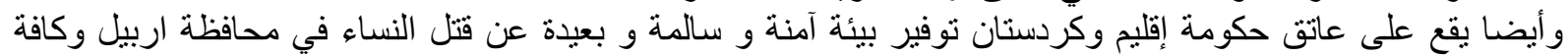

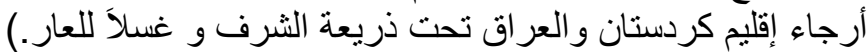

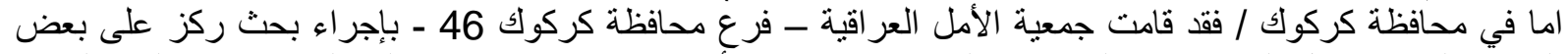

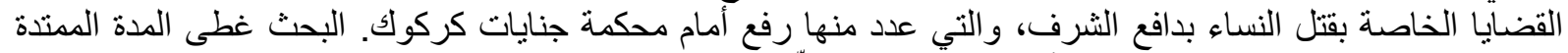

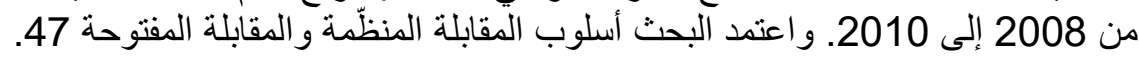

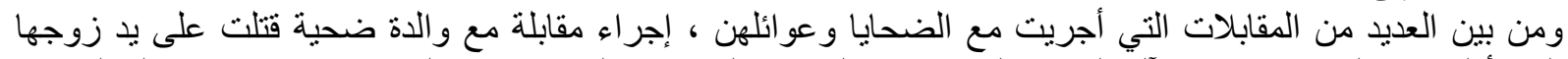

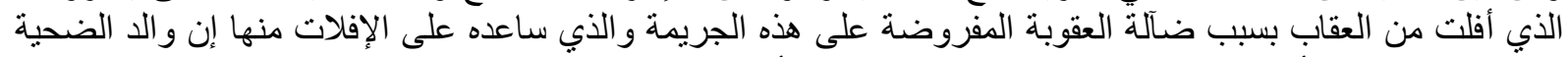

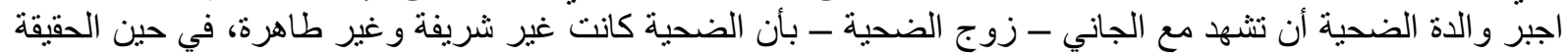

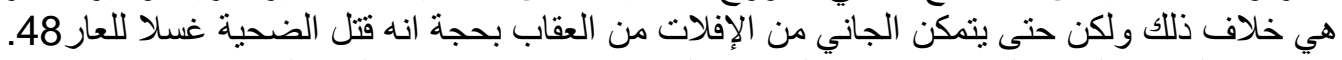

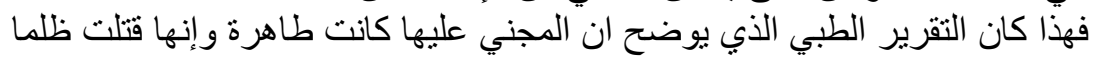

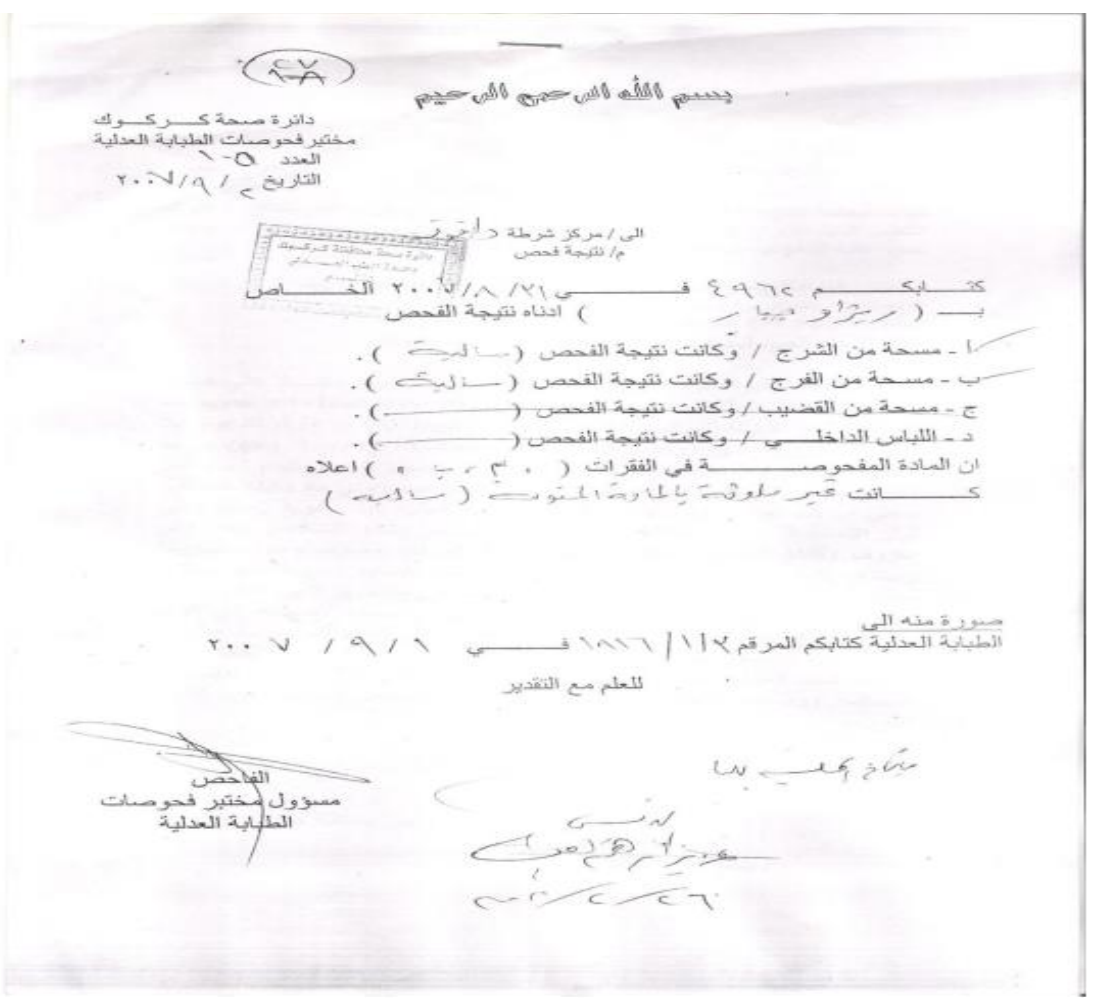

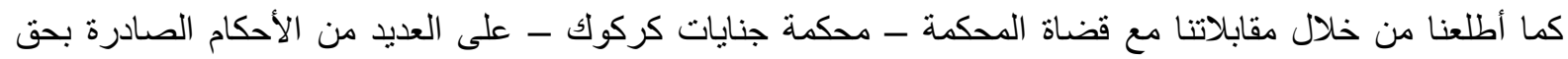

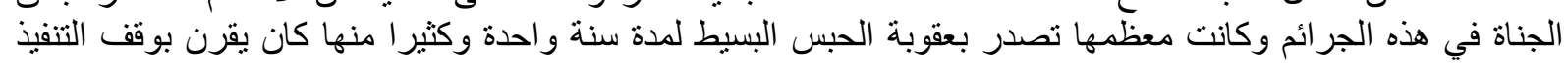

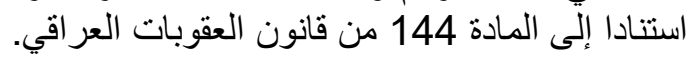




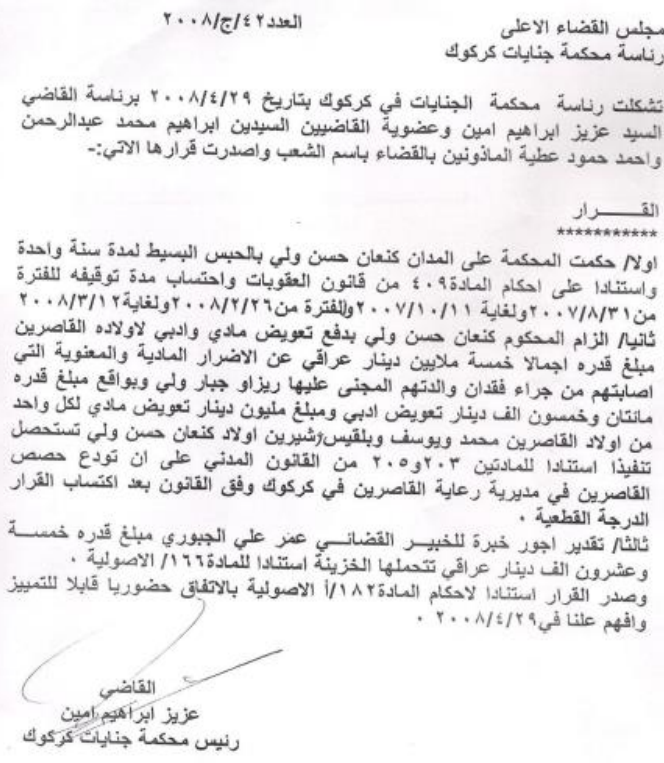

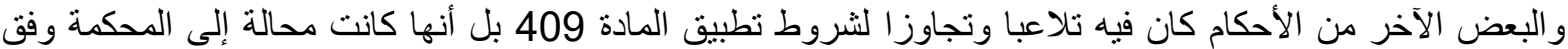

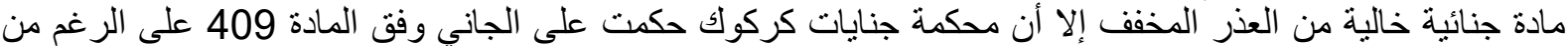
عدم تو افر شروطها في الجاني.

كما أجرينا مقابلات لجناة في جريمة القتل غسلا للعار بعضهم كان غير نادم على جريمته. إلا أن احدهم أدهشنا بما قاله الأه

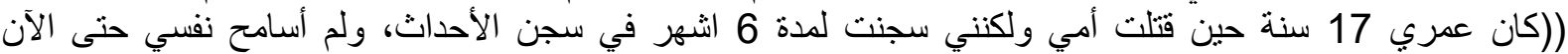

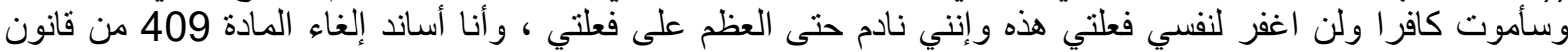

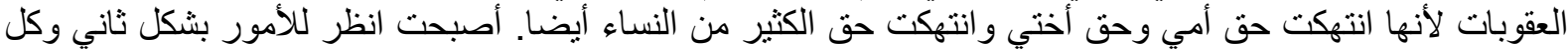
إنسان له حق العيش وليس لأي شخص حق التق انتز اع الحياة منه)) 49. 
كما أجرينا مقابلات لجناة في جريمة القتل غسلا للعار بعضهم كان غير نادم على جريمته. إلا أن احدهم أدهشنا بما قاله

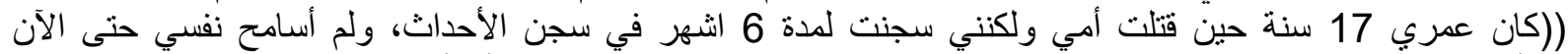

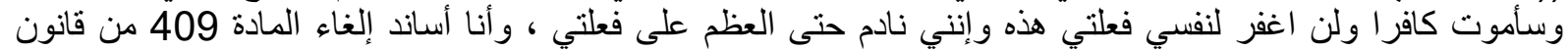

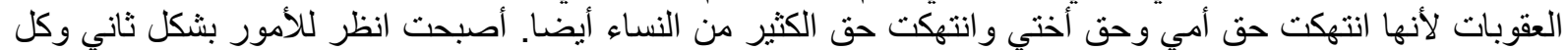

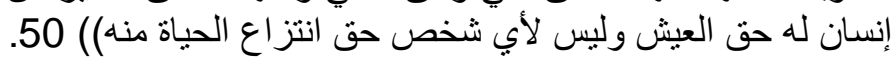
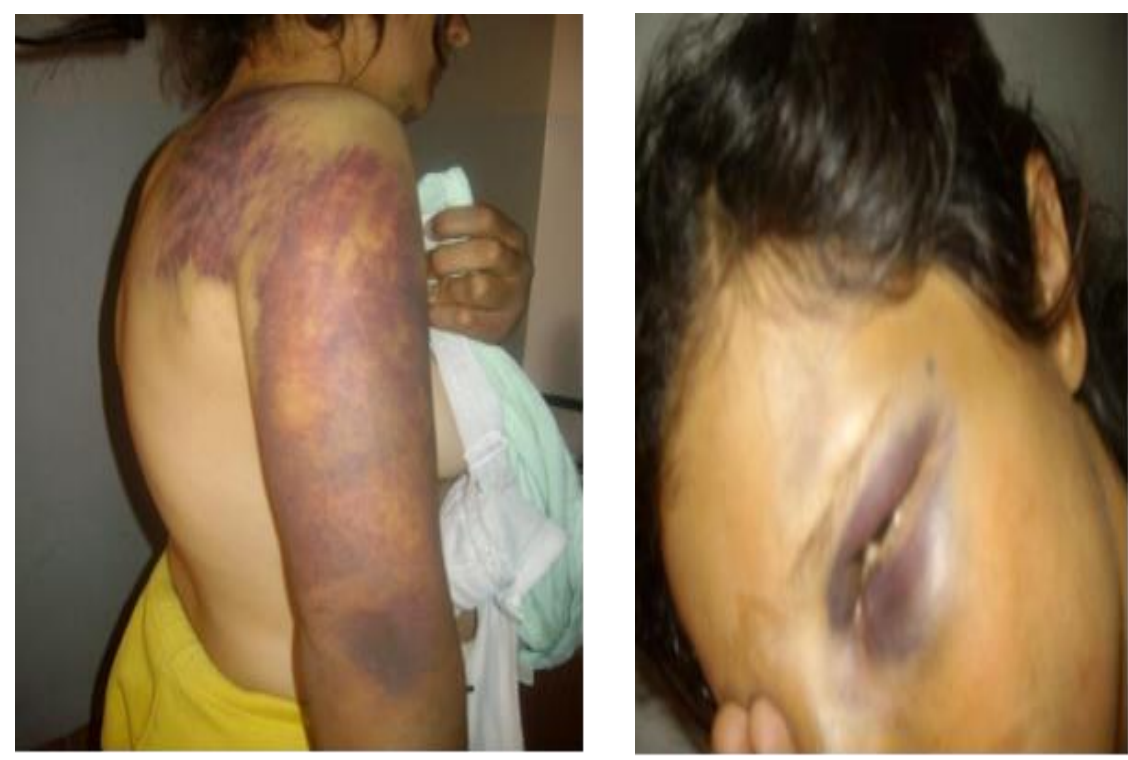

كما التقينا بضحايا ناجيات من الجريمة ، وضحت إحداهن أن زوجها كان يضربها بران بشدة وبقسوة ويريد أن يقتلها ليس لأنها

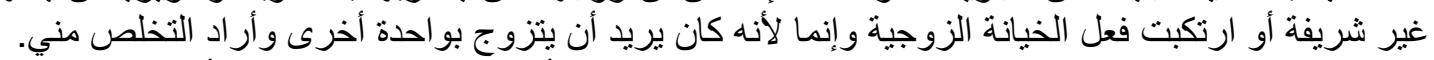

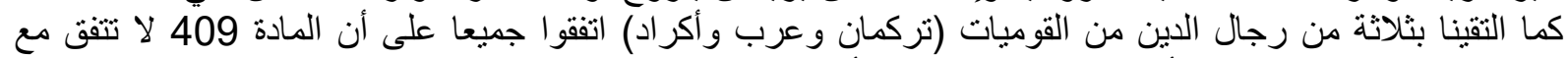

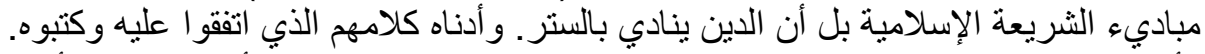

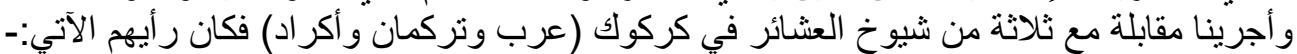

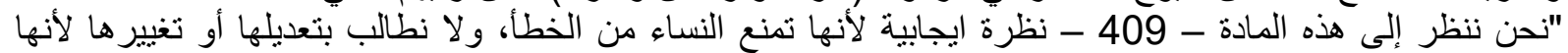

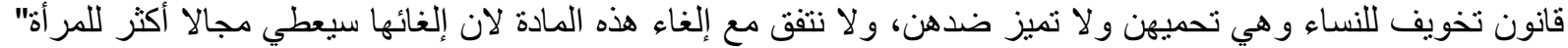

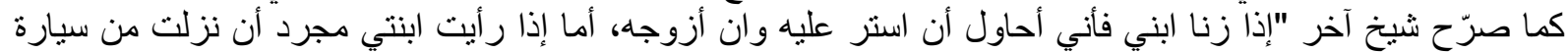

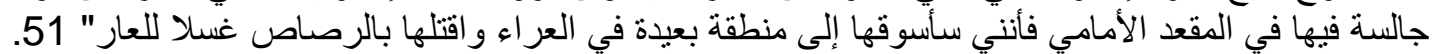

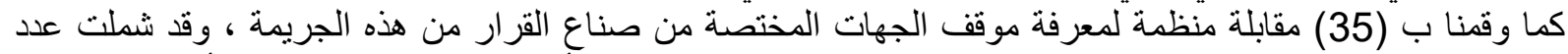

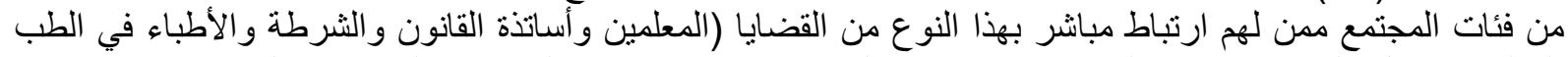

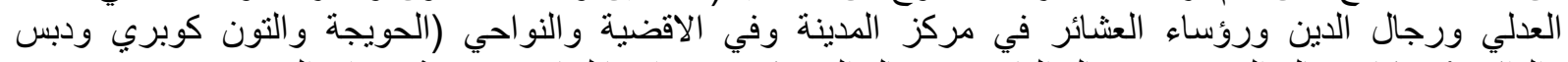

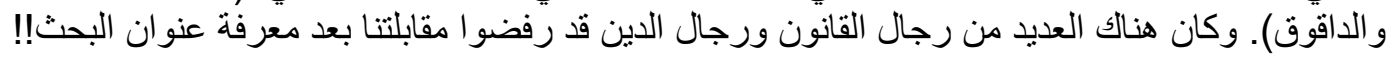

$$
\text { أولا: النتائج الفرع: النتائج والتوصيات التي خرجت بها المنظمات }
$$

1. استخدم عدد من القضاة المادة 409 في قضايا بعيدة عن جرائم الثرف بل في قضايا تخص القتل العدد والضرب الفاب

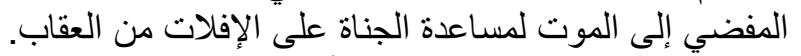

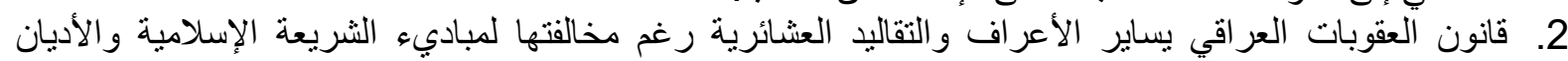

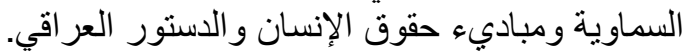

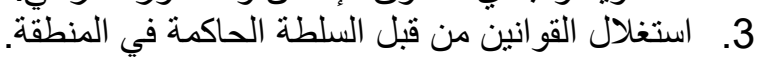
4. تعد المادة 409 من قانون العنان العقوبات العزاقي انتهاكا خطيرا لحقوق الإنسان عموما وحقوق المرأة على وجه الخصوص وتمييز او لا مساو اة بين الجنسين.

5. تحبز بعض الجهات الأمنية و التحقيقية (قضاة، رجال شرطة، محققين) مع المتهم في مثل هكذا قضايا. 
6. سيطرة العادات و التقاليد العشائرية الذكورية على تفكير وقرارات العديد من أجهزة تنفيذ القانون.

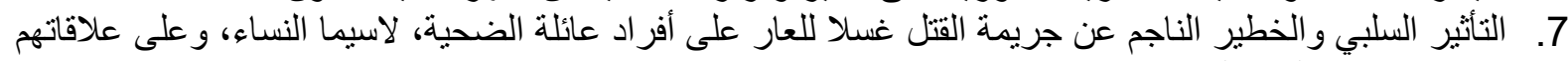

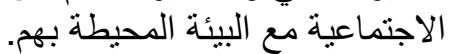

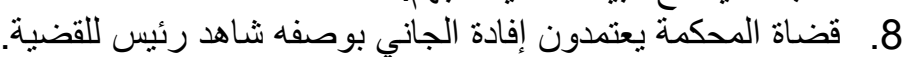

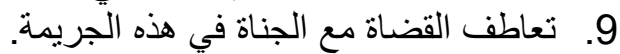

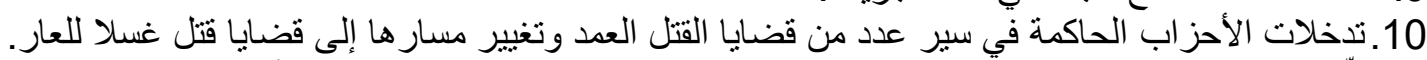

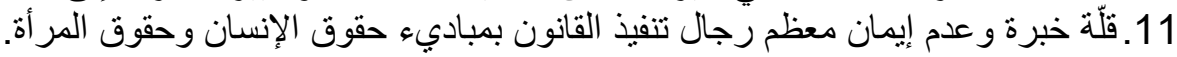

ثثانيا: توصيات منظمات المجتمع المدني الى الحكومة العراقية ومجلس النواب العراقي

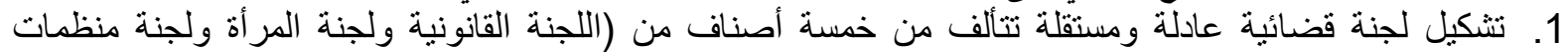

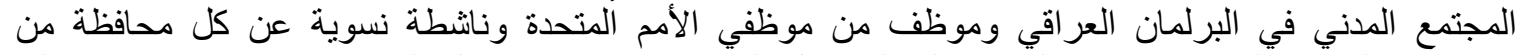

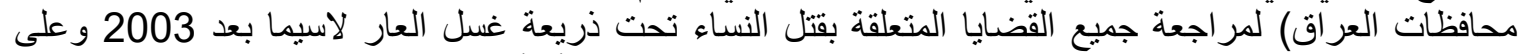

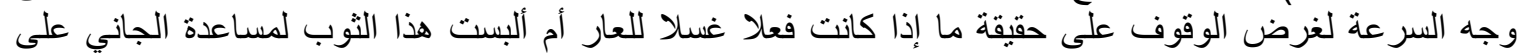
الإفلات من العقاب.

2. إنشاء مديرية متابعة العنف ضداب المر أة تابعة لوزارة الداخلية (تم تنفيذها) و إنشاء ملاجيء حكومية لحماية المرأة

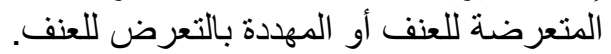

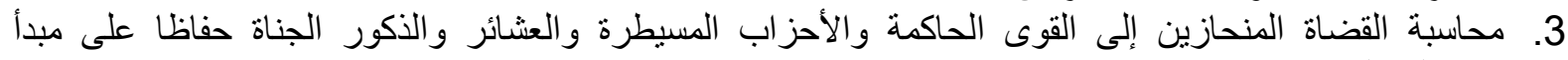
استقلالية القضاء.

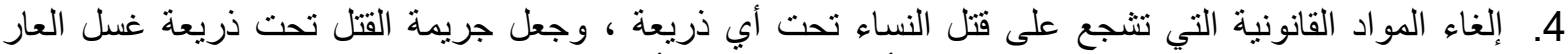

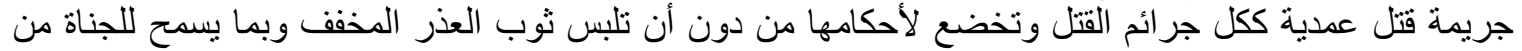

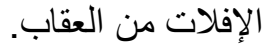
5. تفعيل العمل بالاتفاقيات الدولية واحتر امها كونها جزء من التشريع الوطني لمصادقة العراق عليها. كذلك احترام

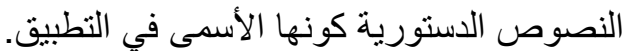

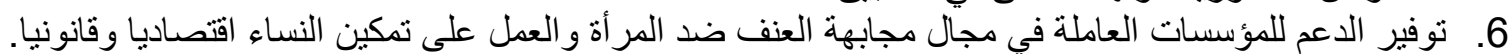

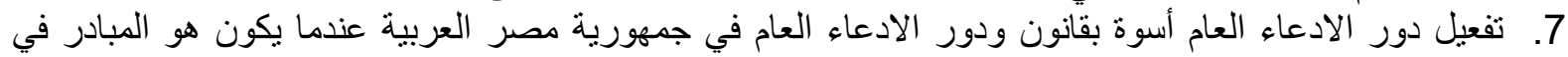

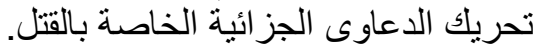

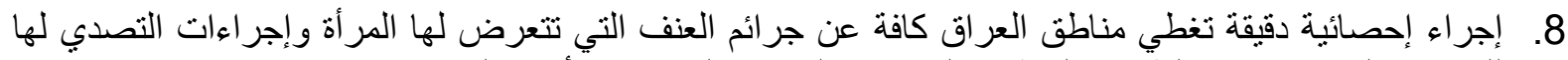

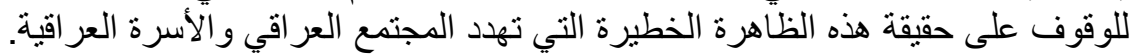

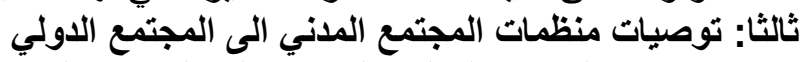

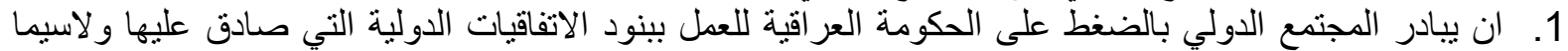

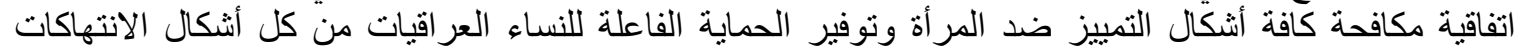
الخطبرة التي تتعرض كافية لها وتهدد أمنها وسلمها. 2. تدريب أجهزة تطبيق وتنفيذ القانون على كيفية احترام حقوق الإنسان وحقوق المرأة وتدريبهة على كيفية التعامل

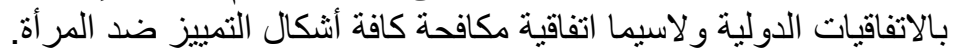

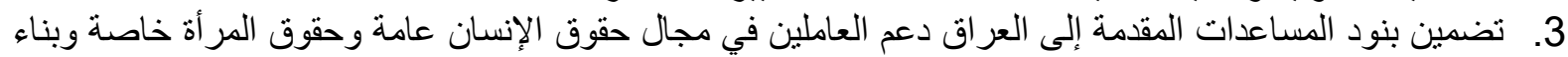

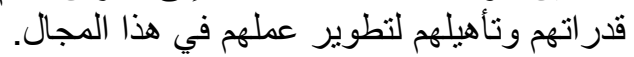

4. دعم نقابة المحامين العر اقية و غير ها من المؤسسات القانونية التي تتولى عملية الدفاع و التمثيل المجاني للضحايا.

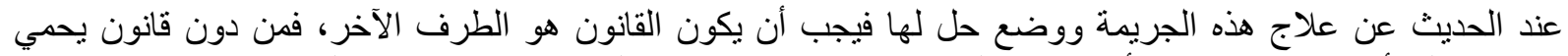

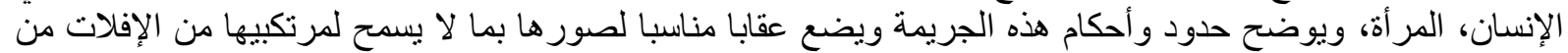

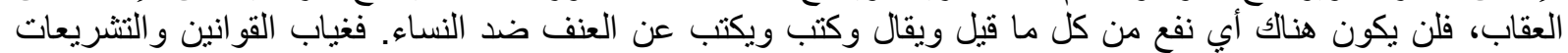

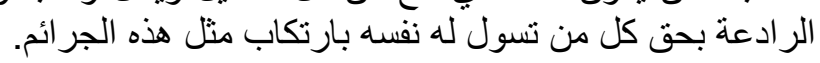




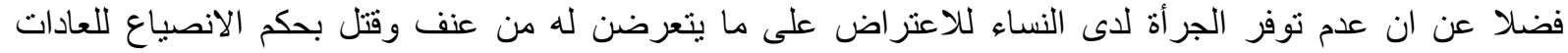

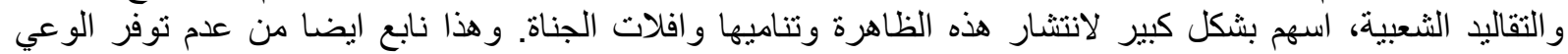

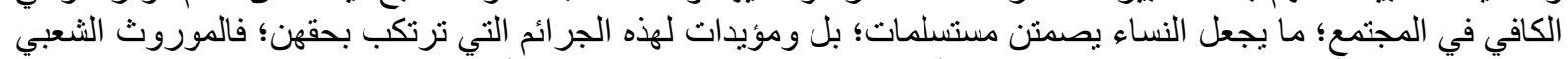

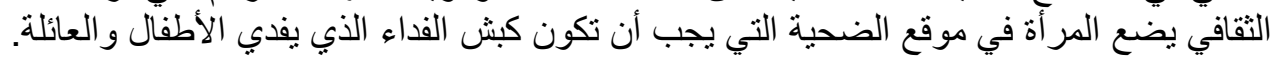

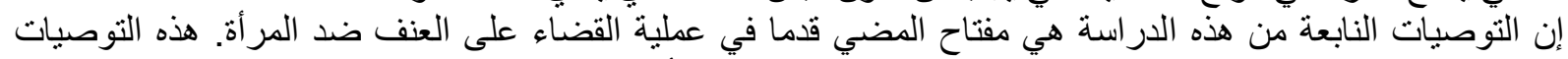

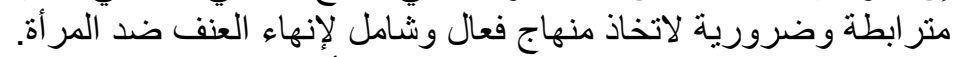

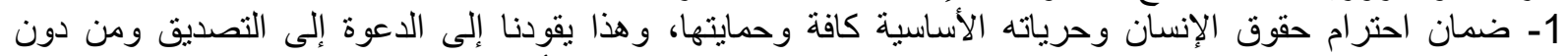

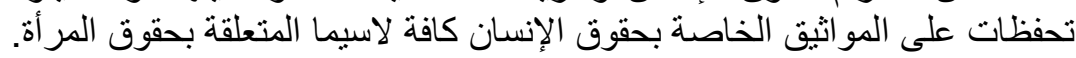

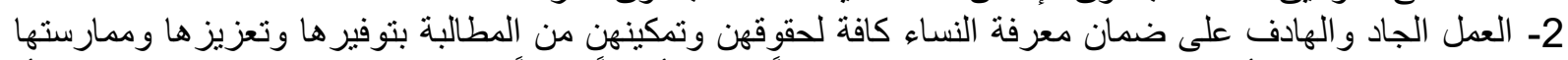

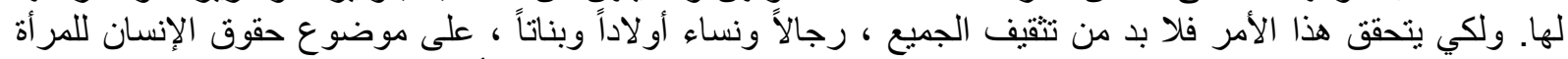

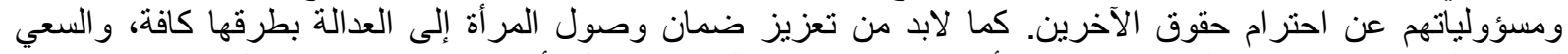

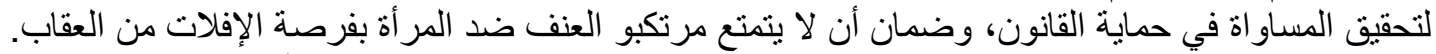

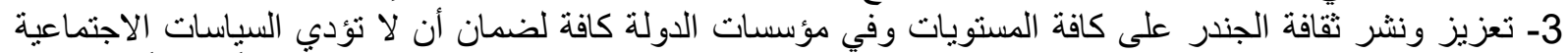

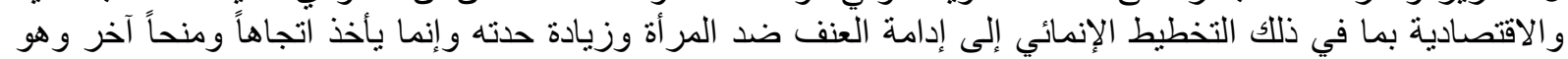

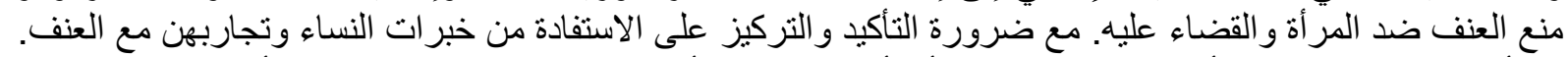

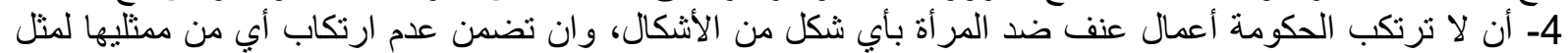

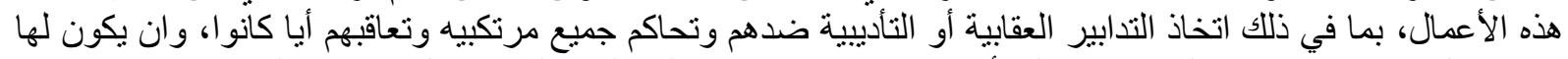

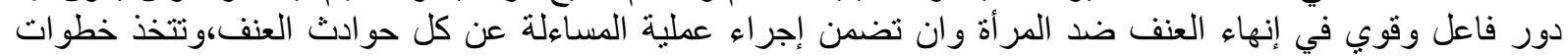

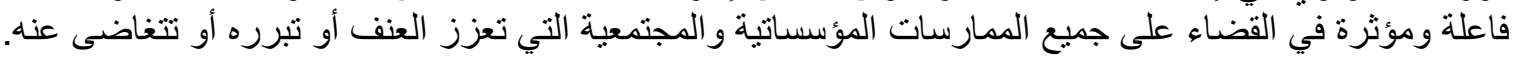

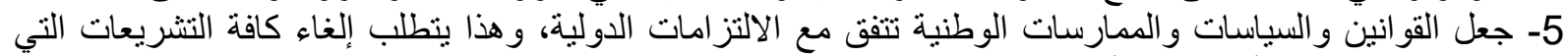

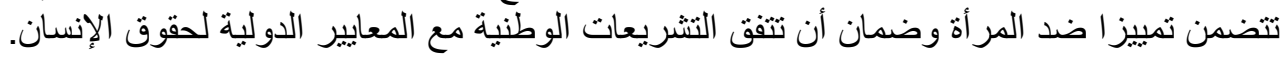

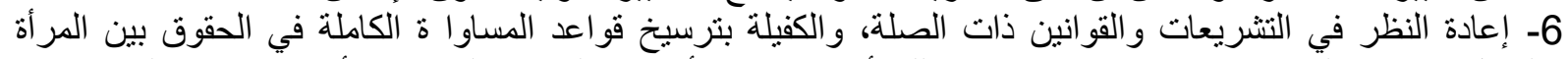

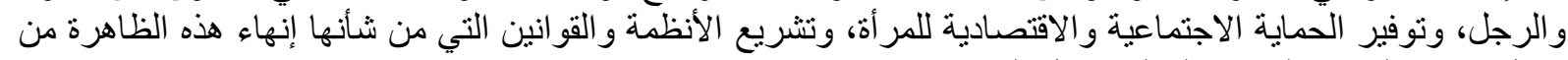

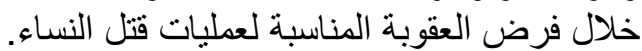

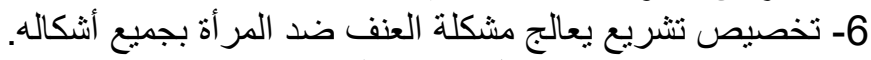

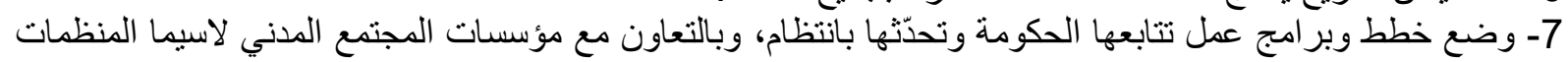

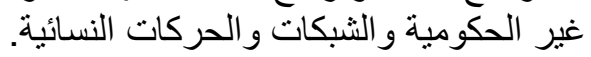

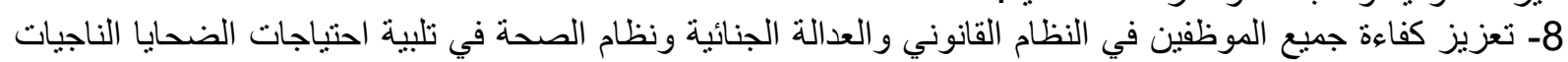

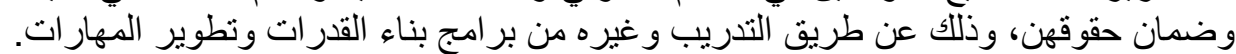

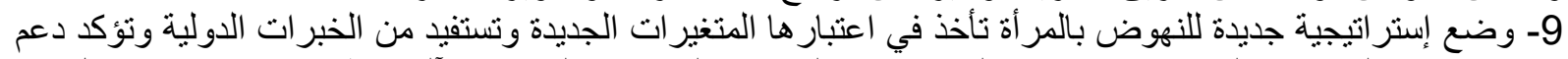

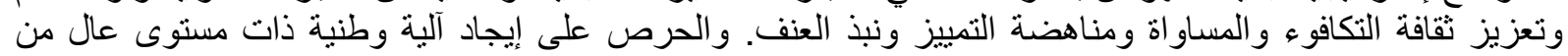

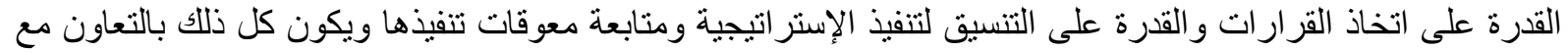
منظمات المجتمع المدني الفاعلة.

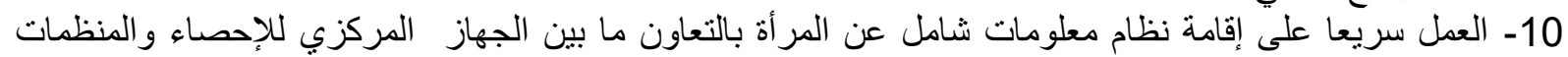

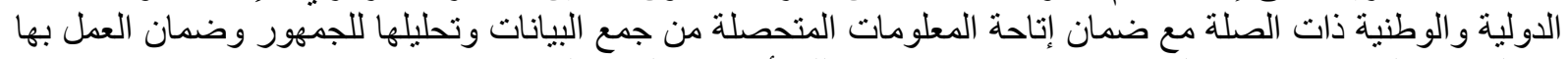

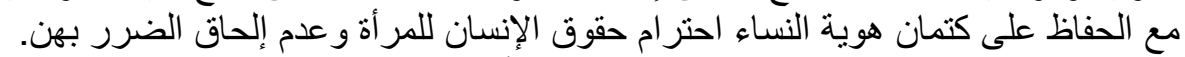

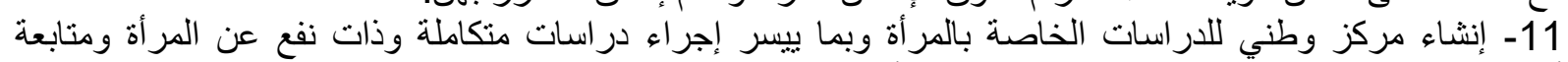

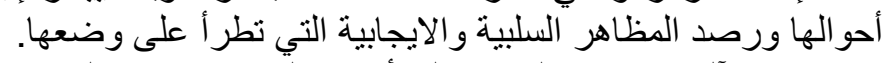

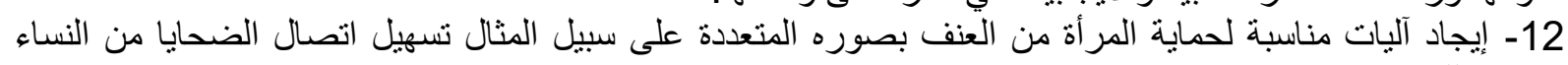
بمر اكز للحماية رسمية وطو عية.

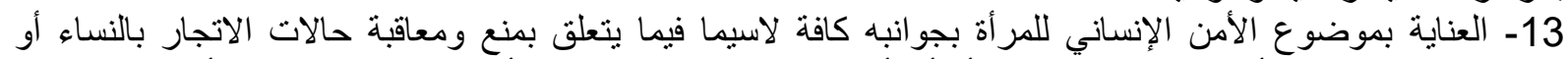

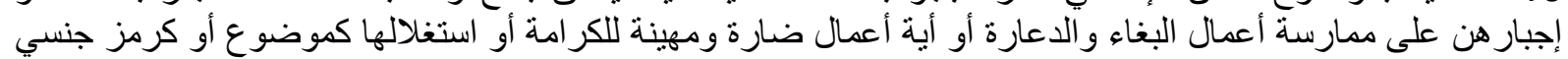

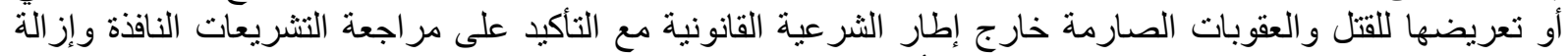

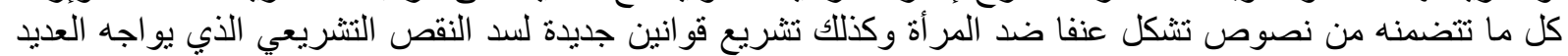

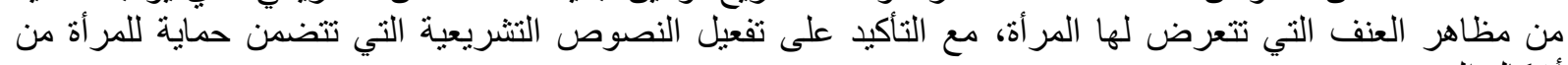

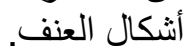

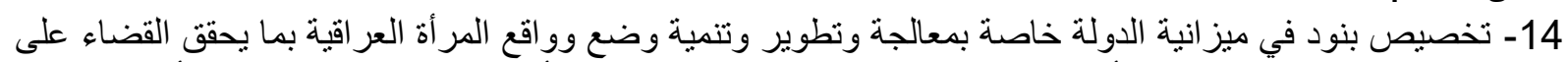

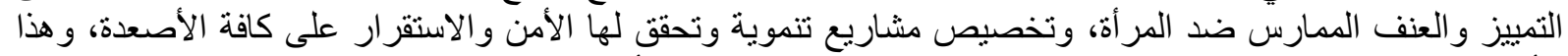

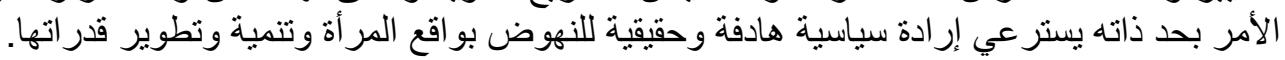




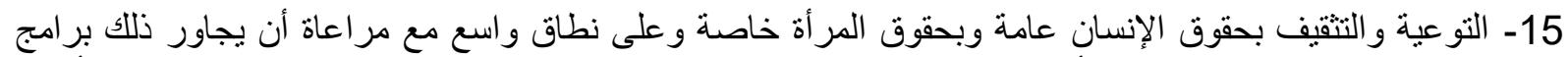

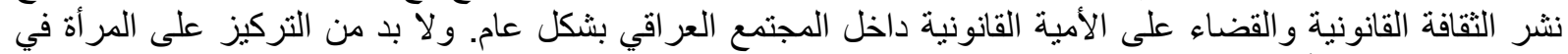

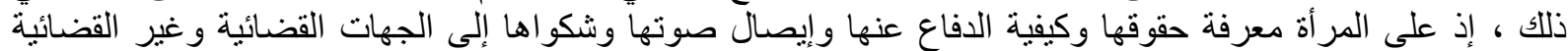

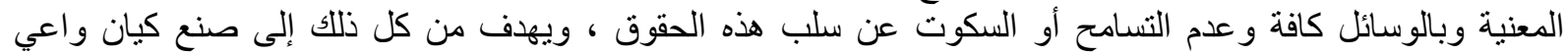

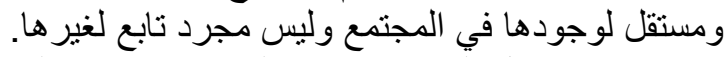

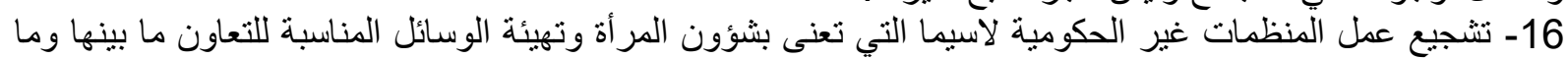
بين المؤسسات الحكومية للتنسيق معها.

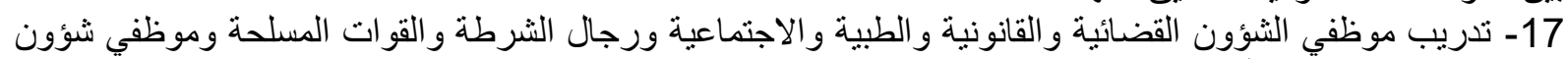

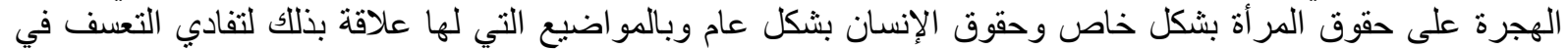

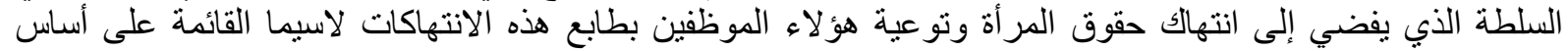

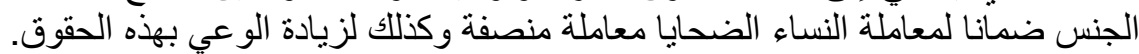

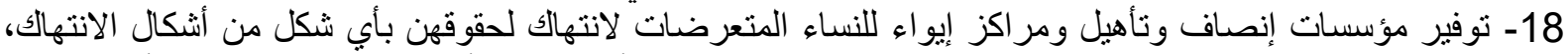

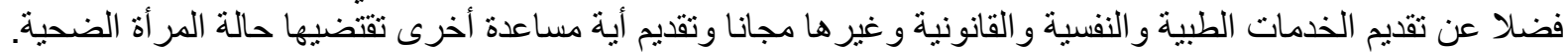

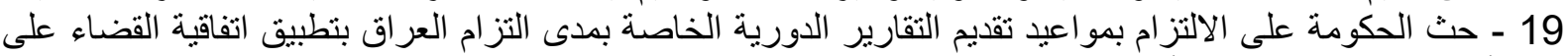

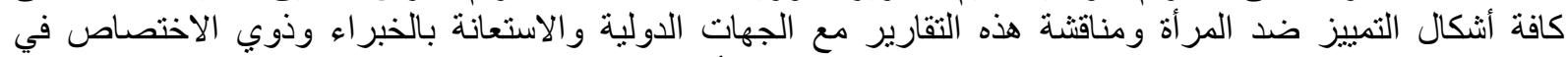

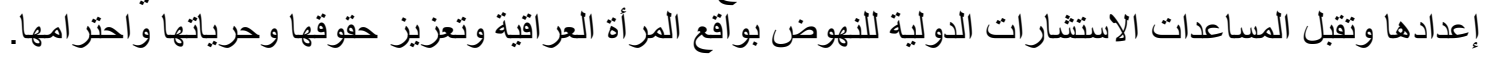

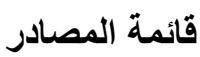

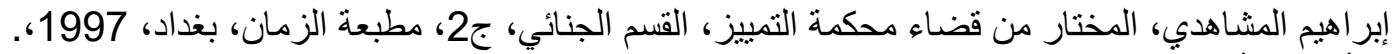

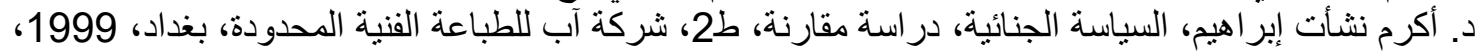

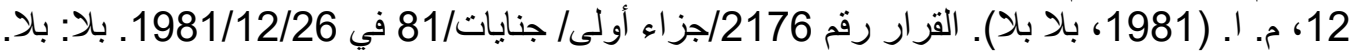

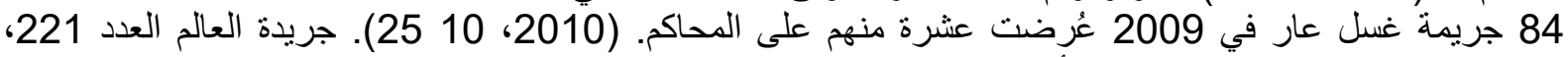

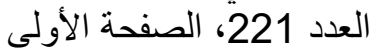

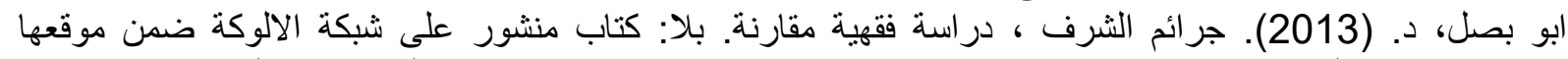
الالكتروني www.alukah.net. Retrieved from كتاب منشور على شبكة الالوكة ضمن موقعها الالكتروني الالكروني

الاعظمي، د. ا. (2002). موسو عة مصطلحات القانون الجنائي (Vol. الطبعة الأولى الجزء الثاني). بغداد، العر اق: دار الثؤون الثقافية العامة.

الجنابي، ق. ت. (2004). المفاجأة بالزنا عنصر استفزاز في القئل القتل والايذاء ، رسالة مقدمة الى كلية القانون جامعة بغداد

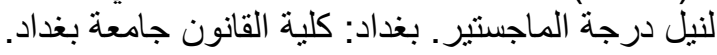

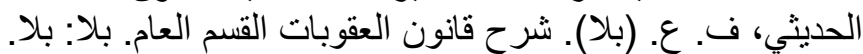

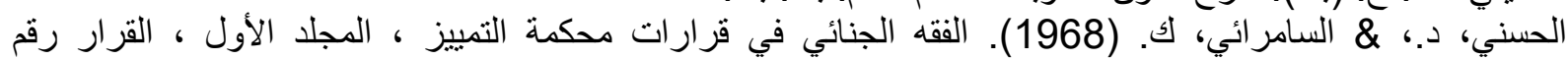

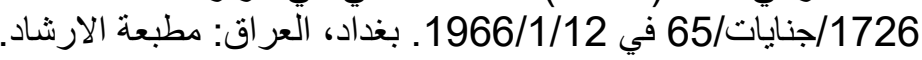

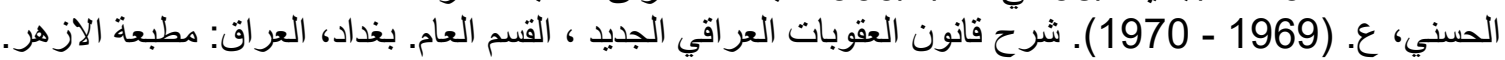

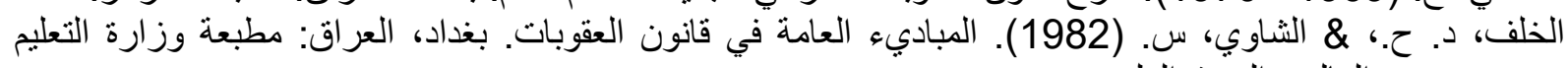

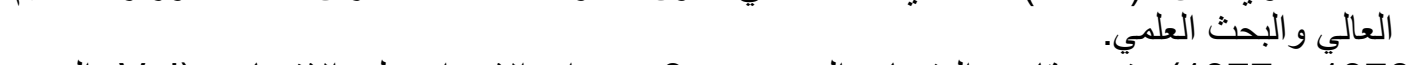

السعدي، د. (1976 - 1977). شرح قانون العقوبات الجديد ، ج 3 ، جرائم الاعتداء على الاشخاص (Vol. لجاء الجزء

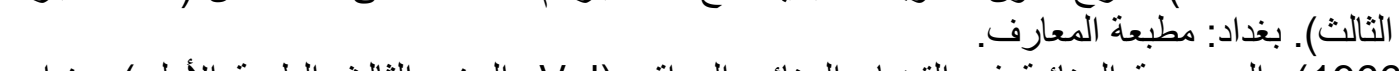

السماك، ع. (1966). الموسوعة الجنائية في القضاء الجنائي العراقي (Vol. الجزءء الثة الثالث الطبعة الأولى). بغداد،

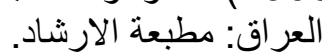

السماك، ع. (1979، بلا بل). الباعث الثريف في قانون العقوبات. مجلة القضاء ، نقابة المحامين في العراق، العدد 1 و .p. 85 ، 2

الثواربي، د. (1985). جريمة الزنا في ضو هو القضاء و والفقه. الاسكندرية، مصر : دار المطبو عات الجديدة.

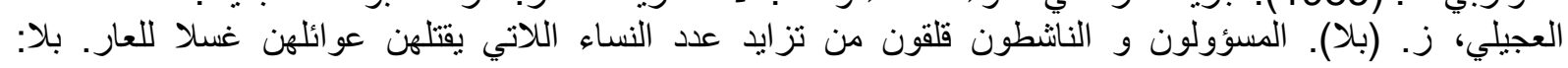
http://niqash.rrizk.com. Retrieved from http://niqash.rrizk.com

الكرباسي، ع. م. (1999). الموسوعة العدلية العدد 39. بغداد، العراق: بلا. 
المتحدة، ت. ا. (2 2 2002 (july). وثيقة الامم المتحدة الجمعية العامة 169 / A الدورة السابعة و الخمسون ، العمل

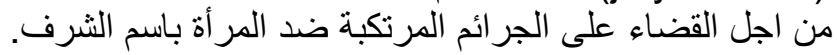

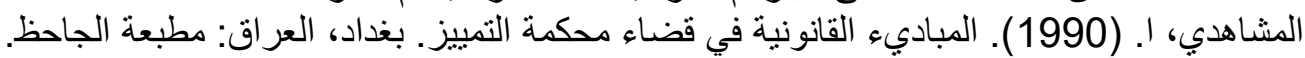

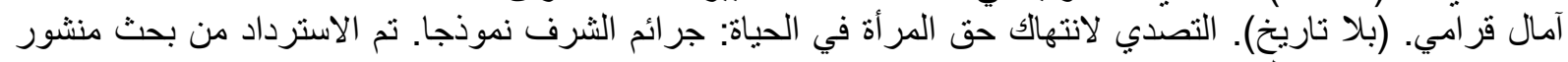

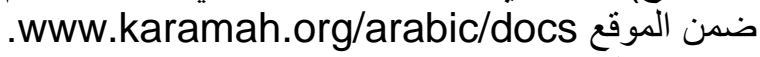

(بلا). تقرير عن جريمة الثرف. بلا: بلا. Retrieved from https://ar.wikipedia.org/wiki عبد الله، م. م. (1975) عنديرة الباعث في قانون العقوبات ، دراسة مقارنة ، رسالة ماجستير. بغداد، العراق: كلبة القانون ،

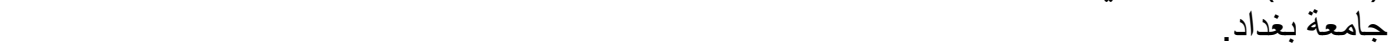
عيسى، ش. ا. (1999). القتل غسلا للعار ، دراسة مقارنة بين الفقه الاسلامي و القانون الوضعي ، رسالة ماجستير.

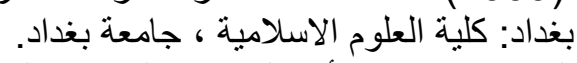

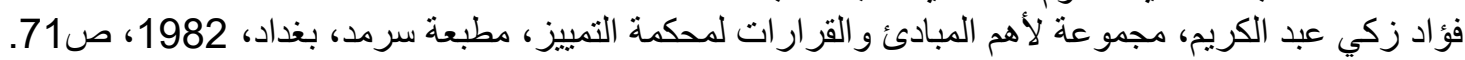

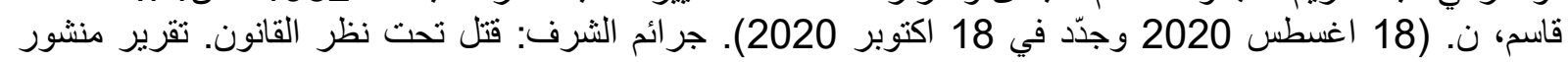

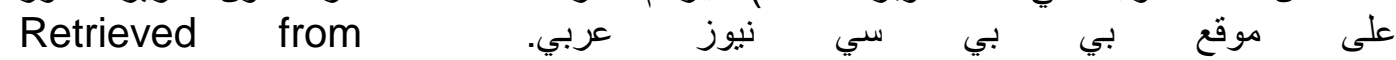
https://www.bbc.com/arabic/features-53752998

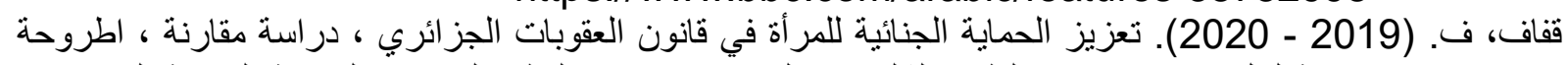

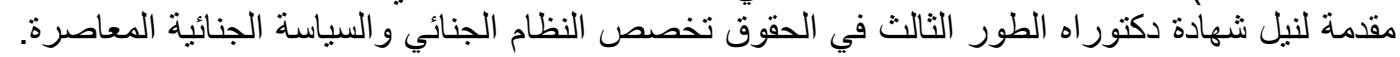

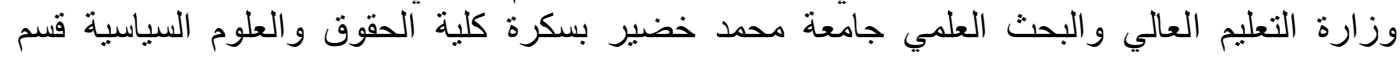

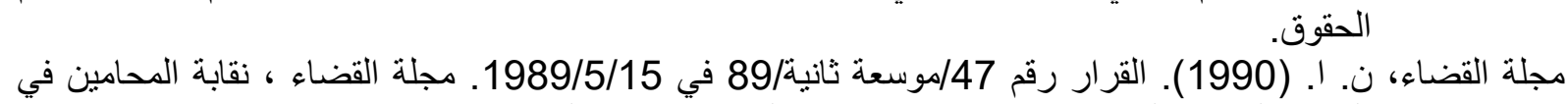

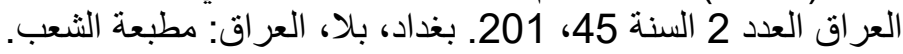

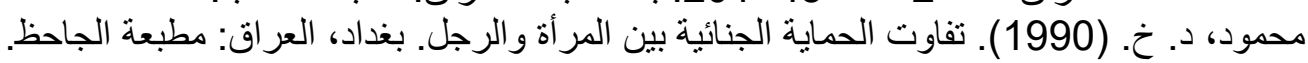

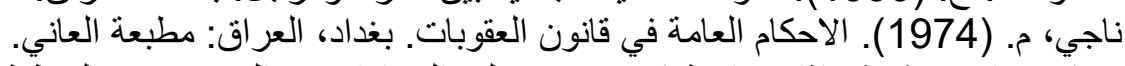

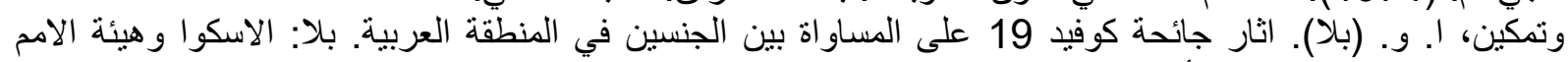

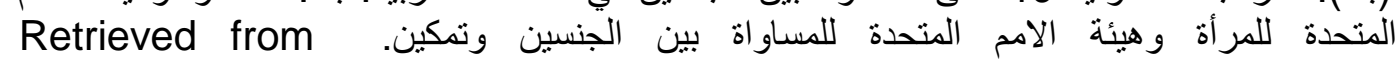

E/ESCWA/2020/Policy Brief.4

د. محمود محمود مصطفى، شرح قانون العقوبات القسم الخاص، ط 8، مطبعة جامعة القاهرة، 1984،

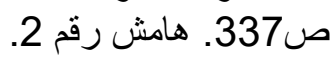

p.16، 1965، London`S. W. Stewart: A modern view of the criminal Law

الهوامش

1 ـ أوقف برلمان الاقليم في اغسطس/آب 2002 العمل بثلاث مو اد من قانون العقوبات العراقي الصادر العام 1969 واهمها القانون الخاص بالقتل

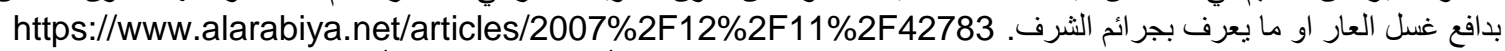

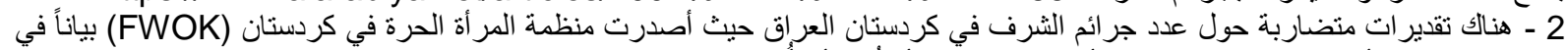

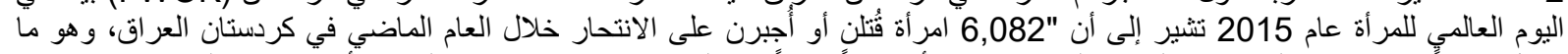

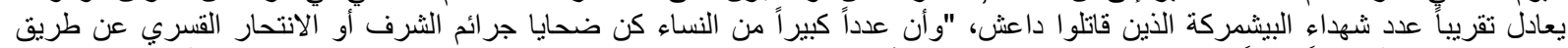

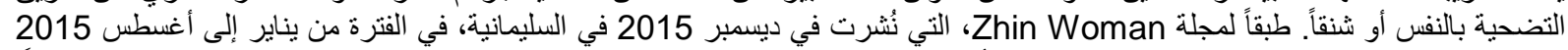

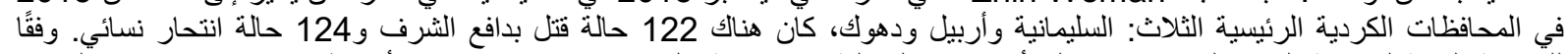

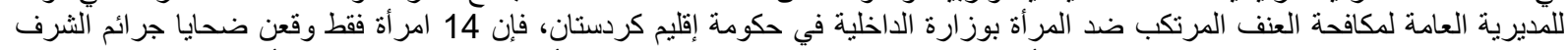

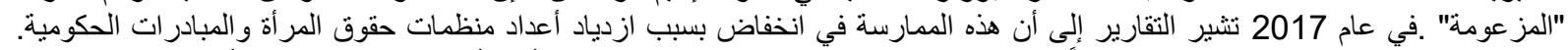

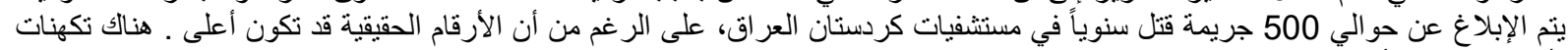

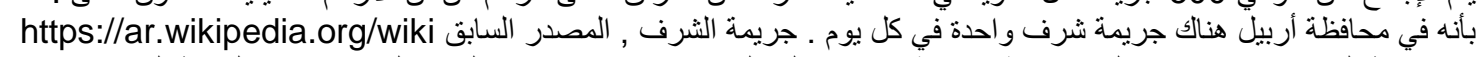

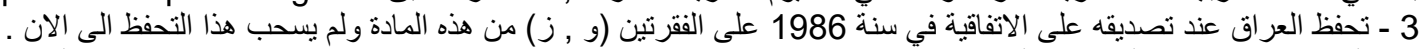

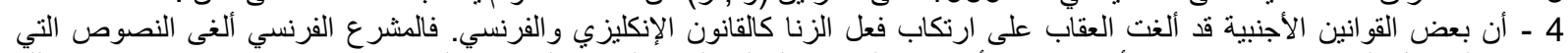

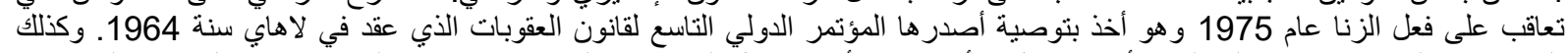

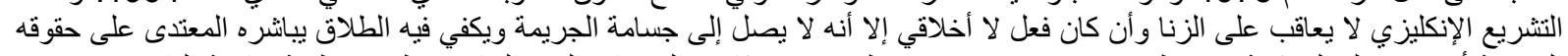

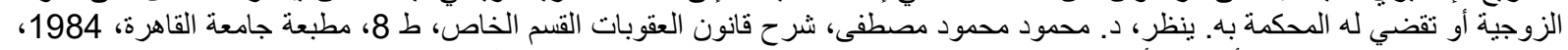
ص337. هامش رقم 2 .د. أكرم نشأت إبراهيه، السياسة الجنائية، دراسة مقارنة، ط2، شركة آب للطباعة الفنية المحدودة، بغداد، 1999، .25 ص.25 5 - عرف الزنا في قانون عقوبات البحرين لسنة 1976، في المادة (150) منأه بأنه (الزنا هو دخول العضو الجنسي للأكر لأقل درجة سواء كان

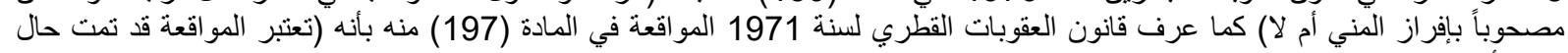

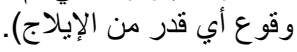


6 - نصت المادة (377) عقوبات عر اقي على أنه (1. تعاقب بالحبس الزوجة الزانية ومن زنا بها... 2. ويعاقب بالعقوبة ذاتها الزوج إذا زنا في منزل الزوجية). 7 - نصت المادة (274) عقوبات مصري على أنه (المر أة المتزوجة التي ثبت زناها يحكم عليها بالحبس ....).

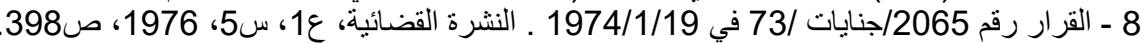

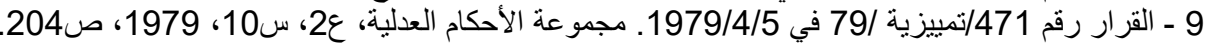

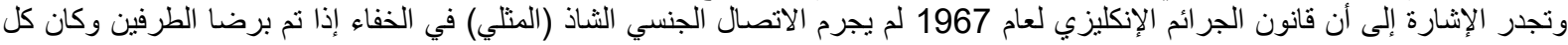

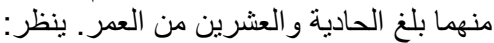

S. W. Stewart: A modern view of the criminal Law, London, 1965, p.16. 10 - القرار رقم 3 /هيئة عامة /94 في 1996/3/20، أنشار إليه علي محمد إبراهيم الكرباسي، الموسوعة العدلية، مرجع سابق، ع39، 1997 197 صن.

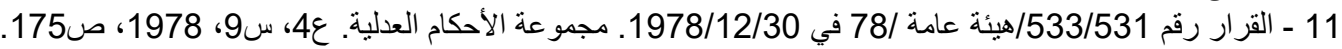
12 - القرار رقم 2218/ جنايات/94/ في 1994/4/21. وبنفس المعنى القرار رقم 1897/ جنايات/94/21 في 1994/3/30. (القرارات غير

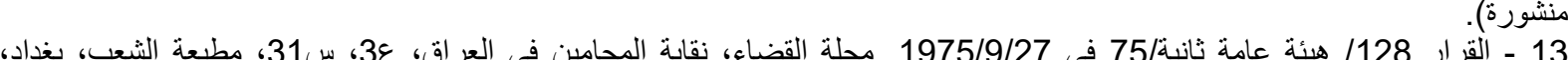

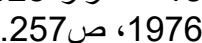

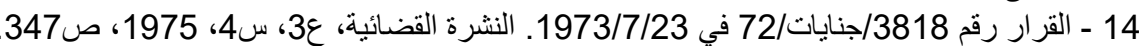

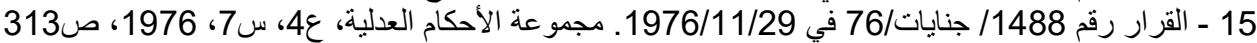

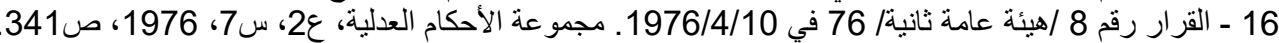

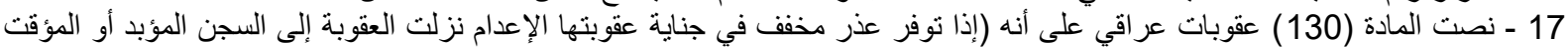

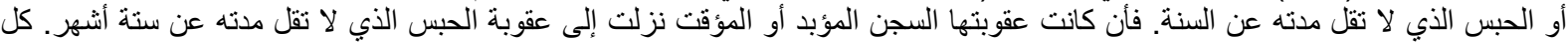
ذللك ما لم ينص القانون على خلافه). 18 - نصات المادة (24) عقوبات على عر اقي على أنى أنه (لا يتغير نوع الجريمة إذا استبدلت المحكة بالعقوبة المقررة لها عقوبة من نوع أخف سواء

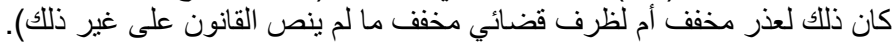

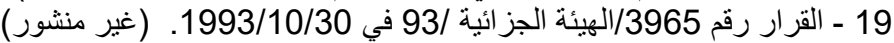

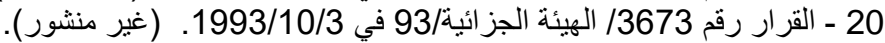

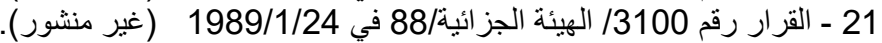

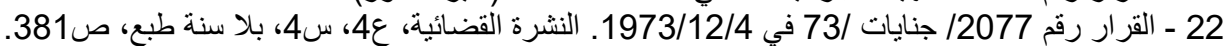

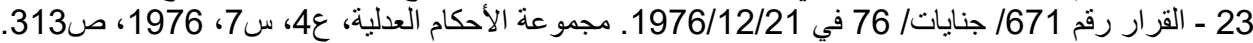

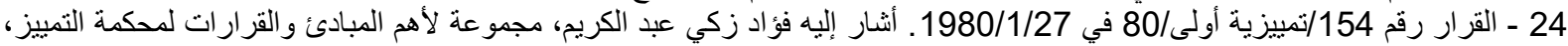

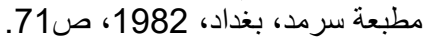

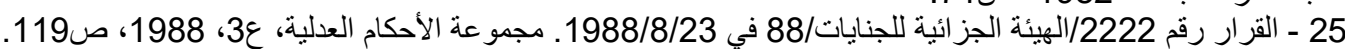

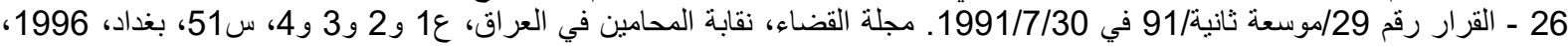
.48

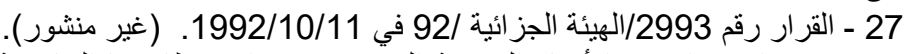

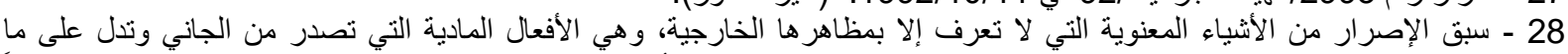

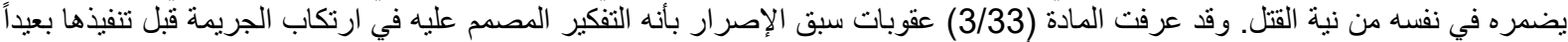
عن ثورة الغضب الآني أو الهياج النفسي. وتطبيقاً لذلك ينظر قرار محكمة التمييز في العراق إق رقم

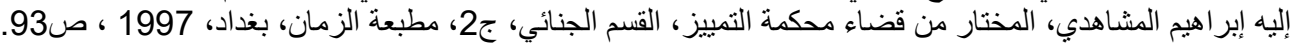

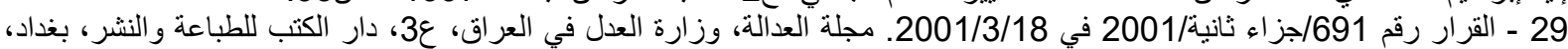

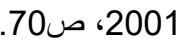

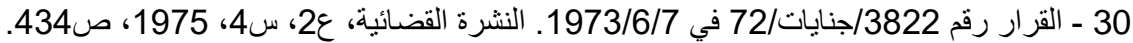

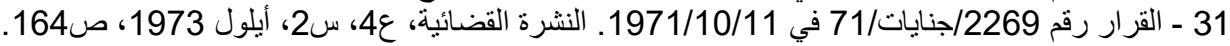

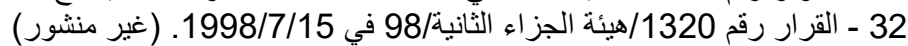

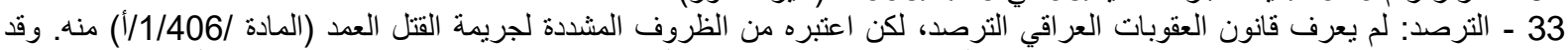

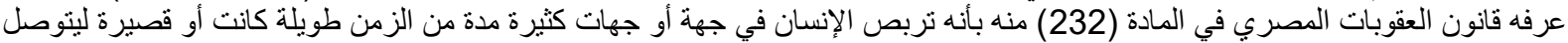

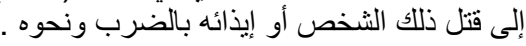

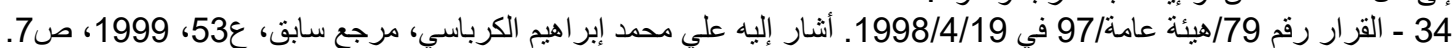

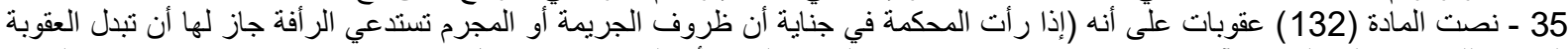

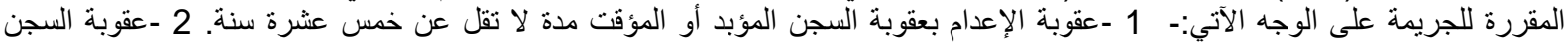

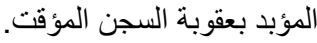
-36عقبة السجن المؤقت بعقوبة الحبس مدة المبن لا تقل عن ستة أشهر).

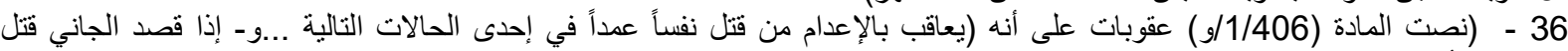
شخصين فأكثر فتم ذللك بفعل واحد.. . ). 
37 - نصت المادة (1/2/406) عقوبات على أنه (وتكون العقوبة الإعدام أو السجن المؤبد في الأحوال التالية.. . أ-إذا قصد الجاني قتل شخص

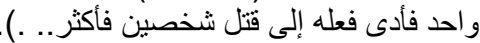

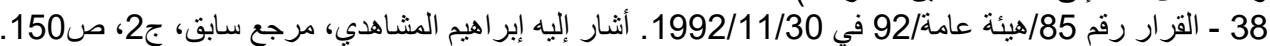

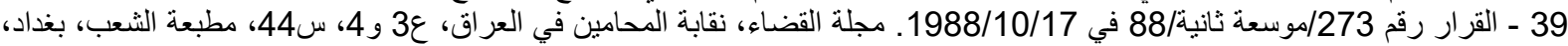

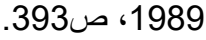

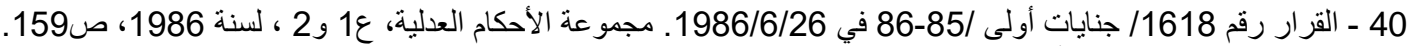

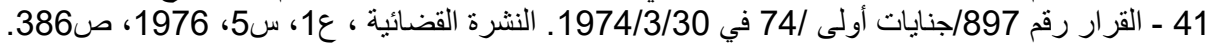

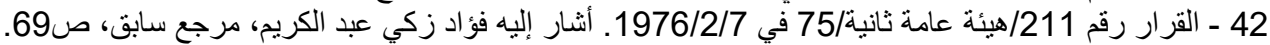

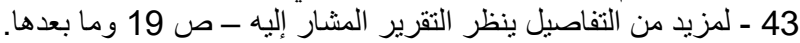

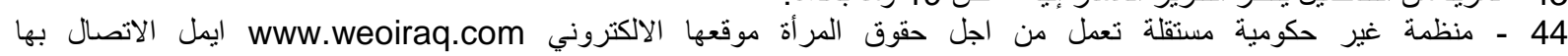
info@weoiraq.com Kurdistan Institute For Human Rights(KIHR - Erbil, Iraq - Koya ) - قاره مان ميند Karaman Mamand - 45 University- The College of Law- E,mail:karaman.mamand@yahoo.com

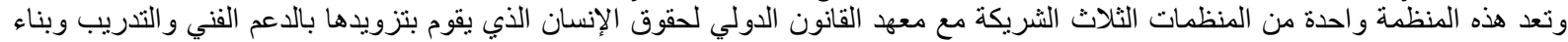

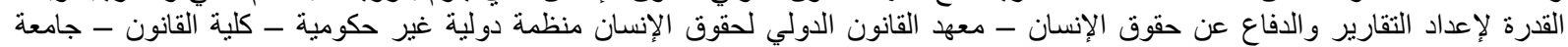
ديبول - شيكاغو www.ihrli-iraq.org Iraqi-alamal.org - 46 - جمعية الامل العراقية منظمة غير حكومية مستقلة تهنم بقضايا حقوق الإنسان عامة وبقضايا حقوق المرأة suroodmf@yahoo.com ولاتصنال وتعد هذه المنظمة واحدة من المنظمات الثالاث الثريكة مع معهد القانون الدولي لحقوق الإنسان الذي يقوم بتزويدها بالاعم الفني والتدريب وبناء

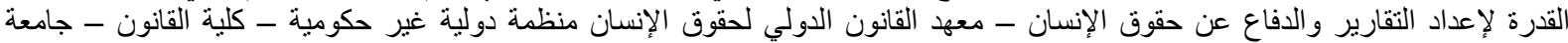
- ديبول - شيكاغو لإن www.ihrli-iraq.org

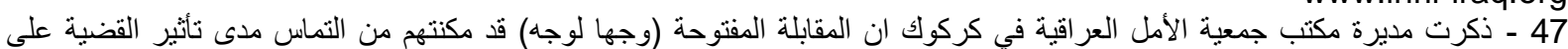

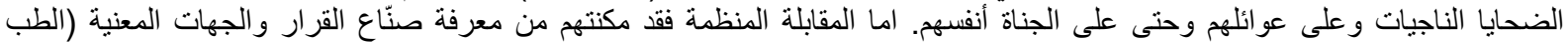

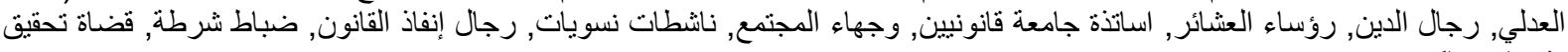

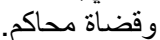

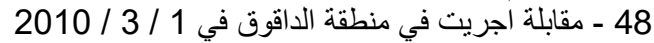

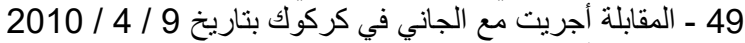

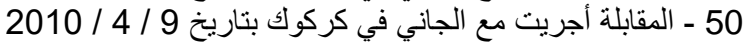
51 - شيوخ قبيلة في كركوك- مديرية شيو اليون العشائر في كركوك بتاريخ 2/ 2010 